Cite this: Dalton Trans., 2014, 43, 6769

Received 19th November 2013, Accepted 16th February 2014

DOI: $10.1039 / c 3 d t 53266 f$

www.rsc.org/dalton

\title{
Facial triad modelling using ferrous pyridinyl prolinate complexes: synthesis and catalytic applications $\uparrow$
}

\author{
Marcel A. H. Moelands, ${ }^{a}$ Daniel J. Schamhart, ${ }^{a}$ Emma Folkertsma, ${ }^{a}$ Martin Lutz, ${ }^{b}$ \\ Anthony L. Spek ${ }^{b}$ and Robertus J. M. Klein Gebbink*a
}

\begin{abstract}
A series of new chiral pyridinyl prolinate (RPyProR) ligands and their corresponding Fe(॥) triflate and chloride complexes are reported. The ligands possess an NN'O coordination motif, as found in the active site of non-heme iron enzymes with the so-called 2-His-1-carboxylate facial triad. The coordination behaviour of these ligands towards iron turned out to be dependent on the counter ion (chloride or triflate), the crystallization conditions (coordinating or non-coordinating solvents) and the presence of substituents on the ligand. In combination with Fe(॥)(OTf $)_{2}$, coordinatively saturated complexes of the type $\left[\mathrm{Fe}(\mathrm{L})_{2}\right](\mathrm{OTf})_{2}$ are formed, in which the ligands adopt a meridional coordination mode. The use of $\mathrm{FeCl}_{2}$ in a non-coordinating solvent leads to 5 -coordinated complexes $\left[\mathrm{Fe}(\mathrm{L})(\mathrm{Cl})_{2}\right]$ with a meridional $\mathrm{N}, \mathrm{N}, \mathrm{O}$ ligand. Crystallization of these complexes from a coordinating solvent leads to 6 -coordinated $\left[\mathrm{Fe}(\mathrm{L})(\mathrm{solv})(\mathrm{Cl})_{2}\right]$ complexes (solv = methanol or acetonitrile), in which the $\mathrm{N}, \mathrm{N}^{\prime}, \mathrm{O}$ ligand is coordinated in a facial manner. For RPyProR ligands bearing a 6-Me substituent on the pyridine ring, solvent coordination and, accordingly, ligand rearrangement are prevented by steric constraints. The complexes were tested as oxidation catalysts in the epoxidation of alkene substrates in acetonitrile with hydrogen peroxide as the oxidant under oxidant limiting conditions. The complexes were shown to be especially active in the epoxidation of styrene type substrates (styrene and trans-beta-methylstyrene). In the best case, complex [Fe(6-MePyProN $\left.\mathrm{N}_{2}\right) \mathrm{Cl}_{2}$ ] (15) allowed for 65\% productive consumption of hydrogen peroxide toward epoxide and benzaldehyde products.
\end{abstract}

\section{Introduction}

Non-heme iron enzymes are involved in a large number of oxidative processes in biology, and their modes of action constitute a source of inspiration for the design of synthetic oxidation catalysts. ${ }^{1}$ In particular, the oxidation of non-activated $\mathrm{C}-\mathrm{H}$ and $\mathrm{C}=\mathrm{C}$ bonds using dioxygen as the formal oxidant is attractive to synthetic chemists. Efforts towards modelling of the active sites of such enzymes have, therefore, not only focused on a further understanding of the enzyme activity and on studying (electronic) structure-activity relationships, but have also focused on the design of bio-inspired oxidation catalysts. ${ }^{2}$

\footnotetext{
${ }^{a}$ Organic Chemistry \& Catalysis, Department of Chemistry, Faculty of Science, Utrecht University, Universiteitsweg 99, 3584 CG Utrecht, The Netherlands. E-mail: r.j.m.kleingebbink@uu.nl

${ }^{b}$ Bijvoet Center for Biomolecular Research, Crystal and Structural Chemistry, Department of Chemistry, Faculty of Science, Utrecht University, Padualaan 8, 3584 CH Utrecht, The Netherlands

$\dagger$ Electronic supplementary information (ESI) available: Details of crystallographic studies. CCDC 972756-972763. For ESI and crystallographic data in CIF or other electronic format see DOI: $10.1039 / \mathrm{c} 3 \mathrm{dt} 53266 \mathrm{f}$
}

Amongst these enzymes, the binuclear enzyme sMMO has attracted a lot of attention over the years because of its property to selectively oxidize methane to methanol. ${ }^{3}$ More recently, a class of mono-nuclear non-heme iron enzymes that possess a so-called 2-His-1-carboxylate facial triad active site have gained widespread interest (Fig. 1). ${ }^{4,5}$ In the active site of these enzymes, the iron centre is surrounded in a facial manner by two histidine ligands and one carboxylate ligand from either glutamate or aspartate. Water molecules occupy the other three sites of the octahedron around iron in the resting state. These three 'vacant' sites are important for the overall reactivity of the enzymes, because they provide binding

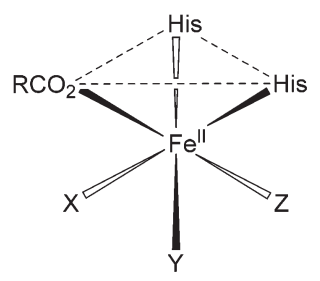

Fig. 1 The 2-His-1-carboxylate facial triad. 
sites for substrate or co-factor molecules that are required for the oxidative transformations carried out by the enzymes.

Most striking, besides the structural aspects of the active sites, is the wide variety in the reaction patterns that are catalysed by the members of the facial triad enzyme family. This reactivity pattern includes, e.g., oxidative ring cleavage, cis-dihydroxylation, hydroxylation, desaturation, ring closure, and ring expansion. For a single structural entity this palette of reactivity is unprecedented in biology and rivals the reactivity diversity displayed by heme enzymes. Not surprisingly, the facial triad enjoys much attention in the bioinorganic field.

Different approaches have been followed to mimic the structural and reactivity features of the facial triad and to comprehend its overall reactivity. Que et al. reported on the preparation of a model of the $\alpha$-ketoglutarate-dependent oxygenases, based on the hydrotris(3,5-diphenylpyrazol-1-yl)borate $\left(\mathrm{Tp}^{\mathrm{Ph} 2}\right)$ ligand that coordinates to iron(II) in a facial manner via three nitrogen donor atoms. ${ }^{6,7}$ Several other all-nitrogen ligands have been used as well to model the facial triad. Examples include tris(2-pyridylmethyl)amine (tpa), ${ }^{8} \mathrm{~N}, \mathrm{~N}$-bis-(2-pyridylmethyl)- $N, N^{\prime}$-dimethyl-1,2-cyclohexanediamine (bpmcn), ${ }^{9}$ and 1,4,7-triazacyclononane (tacn). ${ }^{10}$ Attempts to mimic the structural features of the facial triad coordination environment in a more accurate manner, i.e. through the facial coordination of a combination of two nitrogen-based neutral donors and a mono- or bidentate carboxylate donor, were more recently described. Burzlaff and co-workers reported the coordination chemistry of bispyrazolylacetate heteroscorpionate ligands towards iron. ${ }^{11,12}$ Que and coworkers reported the use of $\mathrm{Ph}$ DPAH (di(2-pyridyl)methylbenzamide) which provides a neutral facial NNO coordination motif. ${ }^{13}$ Interestingly, the complex $\left[\mathrm{Fe}^{\mathrm{II}}(\mathrm{Ph}-\mathrm{DAPH})_{2}\right](\mathrm{OTf})_{2}$ is able to carry out the cis-dihydroxylation of alkenes using $\mathrm{H}_{2} \mathrm{O}_{2}$ as the oxidant and thereby mimics the reactivity of the Rieske dioxygenases. Furthermore, Que and Tolman have reported an alternative strategy to prepare mononuclear iron(II) complexes with an NNO coordination mode, in which sterically encumbered carboxylato ligands in combination with bulky diamine ligands are used. ${ }^{14}$

Our interest in this field is the development of mixed N,O ligands and their use in catalytic oxidation chemistry. In an attempt to closely mimic the electronic properties next to the structural properties of the facial triad, we recently developed the bis(alkyl-imidazol-2-yl)propionate (BAIP) ligand family (Fig. 2A). This ligand family combines a carboxylate donor moiety with two biologically relevant imidazole donor moieties in a predisposed facial manner and enables the synthesis of discrete $\left[\mathrm{M}(\mathrm{BAIP})_{2}\right]$ and $\left[\mathrm{M}(\mathrm{BAIP})(\mathrm{X})_{2} \mathrm{~L}\right]$ complexes, where $\mathrm{M}=$ $\mathrm{Fe}, \mathrm{Cu}, \mathrm{Zn},(\mathrm{X})_{2}$ are two anionic ligands or is a bidentate mono- or dianionic ligand, and $\mathrm{L}$ is a neutral donor ligand like $\mathrm{H}_{2} \mathrm{O}$ or pyridine. ${ }^{15}$ Substitution of the imidazole moieties in the BAIP-ligands allows for the variation of their steric and site isolating, as well as their solubility properties. ${ }^{15 d}$ Complexes of the type $\left[\mathrm{Fe}(\mathrm{BAIP})(\mathrm{cat})\left(\mathrm{H}_{2} \mathrm{O}\right)\right]$, where (cat) is a mono-anionic bidentate (substituted) catechol ligand, were found to react with oxygen to accomplish cleavage of the catechol ring to afford extradiol cleavage products in excess of intradiol
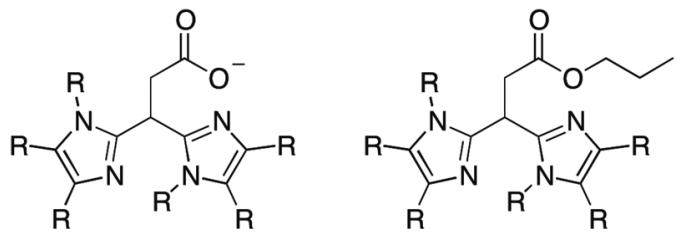

A

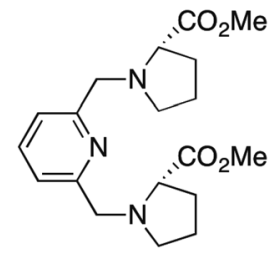

C

Fig. 2 Mixed N,O ligands.

cleavage products (2:1 ratio, respectively) in $60 \%$ yield. $^{16}$ These complexes represent rather accurate structural and functional models for extra-diol cleaving dioxygenase enzymes. Upon substituting the carboxylate moiety in the BAIP ligands for a neutral carboxylic ester moiety (Fig. 2B), the N,N,O facial capping propensity of the ligands is maintained and complexes of the type $\left[\mathrm{Fe}(\mathrm{L})_{2}\right]^{2+}$ are obtained. ${ }^{15 c}$ Complexes of this type were found to be able to catalyze the combined cisdihydroxylation and epoxidation of internal and external olefins. Burzlaff and co-workers have reported independently on the synthesis and metal coordination properties of members of the BAIP-ligand family, ${ }^{17,18}$ while Holland et al. reported on the structure of $\left[\mathrm{Fe}(\mathrm{BAIP})_{2}\right]$ complexes. $^{19}$

In an effort to extend the set of ligands that are able to coordinate to iron in a facial N,N,O manner, we have set out to investigate the coordination chemistry of a set of chiral ligands that would in principle allow for the development of enantioselective bioinspired oxidation catalysts. The investigated set of ligands is composed of a (substituted) pyridine moiety connected to a (substituted) prolinate moiety (Fig. 3). Ligands of this type were earlier reported by Chelucci and co-workers, and have recently been investigated by Paine et al. in combination with iron. ${ }^{20}$ Rutledge and co-workers have also investigated these and related ligands in the iron-mediated oxidation of alkenes (in particular cyclohexene) with $\mathrm{H}_{2} \mathrm{O}_{2} \cdot{ }^{21}$ These pyridinyl prolinate ligands RPyProR are quite easily synthesized using proline and its derivatives as cheap chiral pool synthons. Earlier investigations by us have dealt with analogues of these ligands in which a central pyridine was combined with two proline-derived moieties (Fig. 2C, Py(ProMe) $)_{2}$ ). Those ligands behave as tridentate meridional or planar pentadentate $\mathrm{NN}^{\prime}$ NOO ligands and render diastereopure seven-coordinated metal(II) complexes. ${ }^{22}$

Here, we report on the synthesis and iron(II) coordination properties of ligands 1-8, the structural analysis of the resulting complexes, and report on an initial evaluation of the ability of the resulting iron complexes to catalyse the epoxidation of a series of (pro-chiral) olefin substrates. 

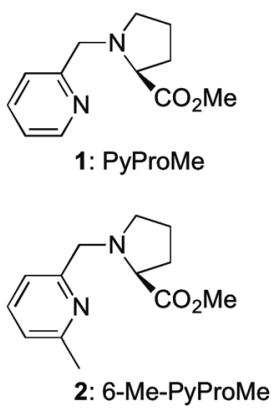

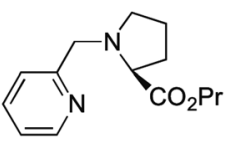

3: PyProPr

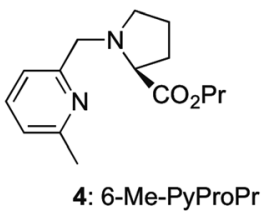

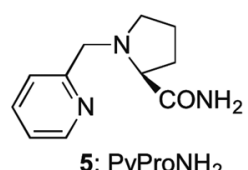

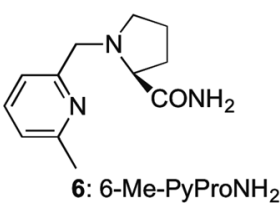

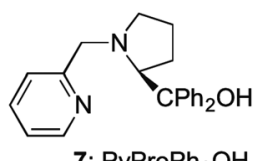

7: $\mathrm{PyProPh}_{2} \mathrm{OH}$

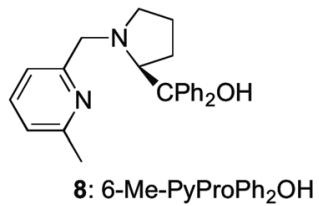

Fig. 3 RPyProR ligands described in this study.

\section{Results}

\section{Ligand synthesis}

The synthesis of the parent ligand PyProMe (1) was earlier reported by Chelucci et $a l^{23}$ Following this synthesis route, ligands 6-Me-PyProMe (2), PyProPr (3), and 6-Me-PyProPr (4) were synthesized using the respective prolinate esters and (substituted) 2-chloromethylpyridine reagents (Scheme 1). Chelucci et al. also reported on the reaction of $\mathbf{1}$ with either $\mathrm{NH}_{3}$ or PhMgBr to afford ligands PyProNH $\mathbf{H}_{2}$ (5) and PyPro$\mathbf{P h}_{2} \mathbf{O H}$ (7), respectively. Amide ligand 6-Me-PyProNH $\mathbf{N H}_{2}$ (6) and prolinol ligand 6-Me-PyProPh $\mathbf{P h}_{2} \mathbf{O H}$ (8) were synthesized in an analogous manner starting from the 2-methylpyridinyl ligand 6-Me-PyProMe (2) (Scheme 1).

\section{Fe-triflate complexes}

We initially studied the complexation behaviour of ligands 1-8 towards Fe(II) triflate, thereby regarding the triflates as noncoordinating anions. A Job plot for ligand $\mathbf{1}$ and $\mathrm{Fe}(\mathrm{OTf})_{2} \cdot 2 \mathrm{MeCN}$ in acetonitrile shows the preferential formation of a $2: 1$ ligand : metal complex, suggesting that 1 acts either as a tridentate ligand to form a hexacoordinated Fe- complex or as a bidentate ligand in combination with solvent or triflate coordination (Fig. 4).

Accordingly, the 2:1 ligand : Fe complexes of ligands 3, 5, and 7 with $\mathrm{Fe}(\mathrm{OTf})_{2} \cdot 2 \mathrm{MeCN}$ were prepared on a preparative scale. To this end one equivalent of $\mathrm{Fe}(\mathrm{OTf})_{2} \cdot 2 \mathrm{MeCN}$ was reacted with two equivalents of the ligand in acetonitrile under an inert $\mathrm{N}_{2}$-atmosphere for $1 \mathrm{~h}$. Isolation via precipi-

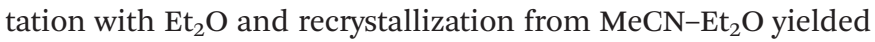
complexes 9-11 as off-white (9 and 11) or yellow (10) powders in $60-90 \%$ yield (Scheme 2). These ferrous complexes are air sensitive and were stored in an inert atmosphere drybox.

ESI-MS analysis of these isolated materials showed monocations of the composition $\left[\mathrm{Fe}(\mathrm{L})_{2}(\mathrm{OTf})\right]^{+}$as the parent peak. Elemental analysis corroborated the anticipated $\mathrm{Fe}(\mathrm{L})_{2}(\mathrm{OTf})_{2}$ composition of the isolated materials. UV-Vis spectra recorded in MeCN showed typical ligand $\pi-\pi^{*}$ and MLCT bands for octahedral Fe(II) complexes below $300 \mathrm{~nm}$ and in the 330-360 nm region, respectively. The solid state IR-spectrum of complex 9 showed a distinctive vibration band at $1658 \mathrm{~cm}^{-1}$ (Fig. 5), indicating that the carbonyl fragments in the complex are coordinated to the metal ion. For the free ligand (3), the carbonyl band is found at $1728 \mathrm{~cm}^{-1}$. The symmetric and asymmetric<smiles>[R]OC1CCCN1</smiles>

$\mathrm{R}=\mathrm{Me}$ $\mathrm{R}=\mathrm{Pr}$<smiles>[R]c1cccc(CC)n1</smiles><smiles>[13CH3][Mg]</smiles>

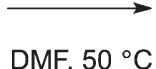
$\mathrm{R}^{\prime}=\mathrm{H}$ $\mathrm{R}^{\prime}=\mathrm{Me}$<smiles>[R]OC(=O)C1CCCN1Cc1cccc([R])n1</smiles>

1: $\mathrm{R}=\mathrm{Me}, \mathrm{R}^{\prime}=\mathrm{H}^{23}$

2: $R=M e, R^{\prime}=\operatorname{Me}(70 \%)$

3: $\mathrm{R}=\mathrm{Pr}, \mathrm{R}^{\prime}=\mathrm{H}(80 \%)$

4: $R=\operatorname{Pr}, R^{\prime}=\operatorname{Me}(89 \%)$<smiles>[R]c1cccc(CN2CCC[C@H]2C(N)=O)n1</smiles>

5: $\mathrm{R}^{\prime}=\mathrm{H}$

6: $\mathrm{R}^{\prime}=\mathrm{Me}$<smiles>[R]C(=O)C1CCCN1Cc1ccc([NH3+])nc1</smiles>

1: $\mathrm{R}^{\prime}=\mathrm{H}$

2: $\mathrm{R}^{\prime}=\mathrm{Me}$<smiles>[R]c1cccc(CN2CCC[C@H]2c2ccccc2)n1</smiles>

7: $\mathrm{R}^{\prime}=\mathrm{H}^{23}$

8: $R^{\prime}=\operatorname{Me}(85 \%)$

Scheme 1 Synthesis of ligands 1-8. 


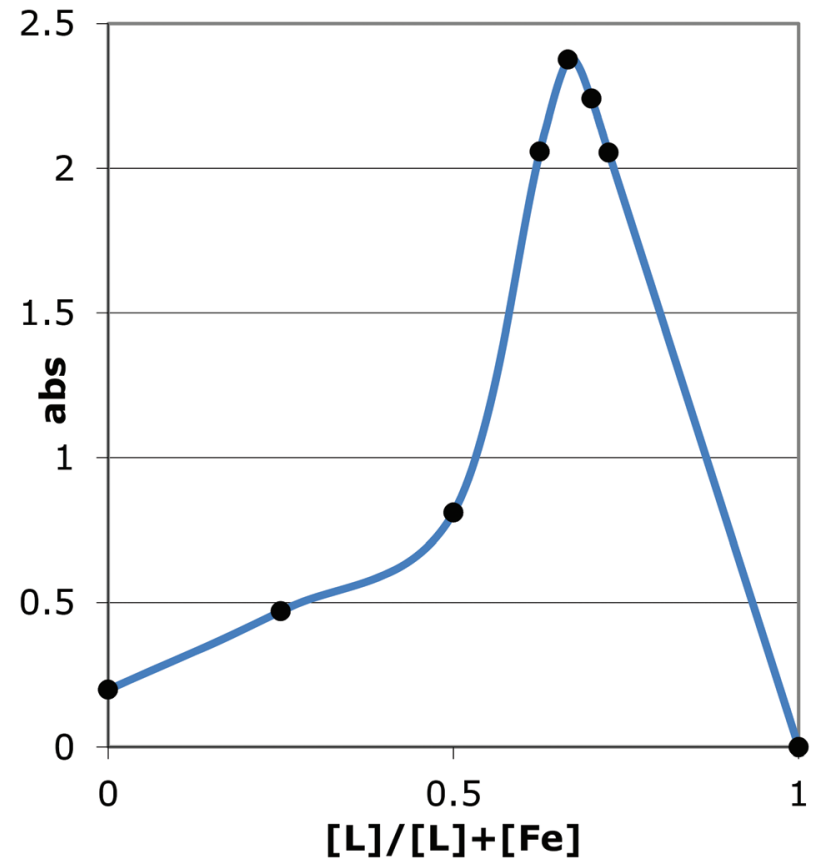

Fig. 4 Job plot between $\mathrm{Fe}(\mathrm{OTf})_{2} \cdot 2 \mathrm{MeCN}$ and ligand 1; the black dots represent the data points.

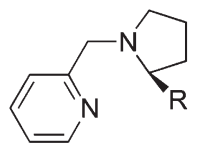

3: $\mathrm{R}=\mathrm{CO}_{2}{ }^{\mathrm{n}} \mathrm{Pr}$

5: $\mathrm{R}=\mathrm{CONH}_{2}$

7: $\mathrm{R}=\mathrm{CPh}_{2} \mathrm{OH}$
$\mathrm{Fe}(\mathrm{OTf})_{2} \cdot 2 \mathrm{MeCN}$

$(0.5 \mathrm{eq})$

$\mathrm{MeCN}$

9: $\mathrm{R}=\mathrm{CO}_{2}{ }^{\mathrm{n}} \mathrm{Pr} ;\left[\mathrm{Fe}^{\mathrm{ll}}\left(\mathrm{PyPro}{ }^{\mathrm{n}} \mathrm{Pr}\right)_{2}\right](\mathrm{OTf})_{2}$

10: $\mathrm{R}=\mathrm{CONH}_{2} ;\left[\mathrm{Fe}{ }^{\|}\left(\text {PyProNH }_{2}\right)_{2}\right](\mathrm{OTf})_{2}$

11: $\mathrm{R}=\mathrm{CPh}{ }_{2} \mathrm{OH} ;\left[\mathrm{Fe}^{\prime \prime}\left(\mathrm{PyPrOPh}_{2} \mathrm{OH}\right)_{2}\right](\mathrm{OTf})_{2}$
Scheme 2 Synthesis of the triflate complexes 9-11.

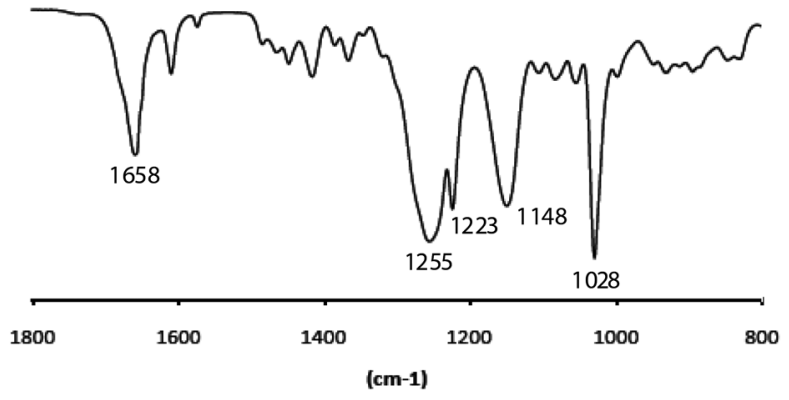

Fig. 5 Solid state IR spectrum of complex 9.

vibrations of the $\mathrm{CF}_{3}$ and $\mathrm{SO}_{3}$ groups in 9 are found at 1255 $\left(\nu_{\text {as }} \mathrm{SO}_{3}\right), 1223\left(\nu_{\mathrm{s}} \mathrm{CF}_{3}\right), 1148\left(\nu_{\mathrm{as}} \mathrm{CF}_{3}\right)$ and $1028\left(\nu_{\mathrm{s}} \mathrm{SO}_{3}\right) \mathrm{cm}^{-1}$, which points at the presence of non-coordinating triflate groups. $^{24}$

Similar observations were made in the solution IR-spectrum (MeCN) of complex 9. This indicates that no structural changes related to both carbonyl or triflate coordination take place and that the overall solid-state structure of 9 is maintained in solution. For solid complex 10, the position of the carbonyl band at $1673 \mathrm{~cm}^{-1}$ also indicates coordination of this group to iron. In the free ligand (5), this band is also found at a relatively low energy $\left(1669 \mathrm{~cm}^{-1}\right)$, which is most likely caused by intermolecular hydrogen bonding between carbonyl and amino groups. The position of the triflate bands also indicates that these ions are not coordinated to iron in complex 10; vibration bands for the triflate groups are found at 1270 $\left(\nu_{\mathrm{as}} \mathrm{SO}_{3}\right), 1227\left(\nu_{\mathrm{s}} \mathrm{CF}_{3}\right), 1158\left(\nu_{\mathrm{as}} \mathrm{CF}_{3}\right)$ and $1031\left(\nu_{\mathrm{s}} \mathrm{SO}_{3}\right) \mathrm{cm}^{-1}$. For complex 11, the situation is slightly different as the complex does not contain carbonyl groupings, but instead contains tertiary alcohol groupings. In the IR-spectra of complex 11 a broad peak is observed for the $\mathrm{OH}$ group around $3339 \mathrm{~cm}^{-1}$. The peak of the $\mathrm{OH}$ group in the free ligand is found at a higher wavenumber $\left(3395 \mathrm{~cm}^{-1}\right)$. The ROH groups in this complex most likely coordinate to iron, whereas they are not deprotonated according to the parent peak observed in ESI-MS ([Fe(PyProPh $\left.\left.\left.{ }_{2} \mathrm{OH}\right)_{2}(\mathrm{OTf})\right]^{+}, m / z=893.269\right)$. The triflate groups in this complex are just as for complexes $\mathbf{9}$ and $\mathbf{1 0}$ not coordinated towards the iron centre; triflate vibrations are found at $1277\left(\nu_{\mathrm{as}} \mathrm{SO}_{3}\right), 1223\left(\nu_{\mathrm{s}} \mathrm{CF}_{3}\right), 1157\left(\nu_{\mathrm{as}} \mathrm{CF}_{3}\right)$ and 1027 $\left(\nu_{\mathrm{s}} \mathrm{SO}_{3}\right) \mathrm{cm}^{-1}$ for complex 11.

Magnetic susceptibility measurements in solution using Evans' method ${ }^{25,26}$ indicated $\mu_{\text {eff }}$ values of 4.86 (9, acetone), $4.46(10, \mathrm{MeCN})$ and $4.58(11, \mathrm{MeCN}) \mu_{\beta}$ for these complexes. While these values are somewhat below the theoretical value of 4.92 for an $S=2$ system, these do indicate a high spin configuration for these iron(II) triflate complexes.

Twinned crystals suitable for X-ray diffraction were obtained for complex $\left[\mathrm{Fe}\left(\mathbf{P y P r o N H}_{2}\right)_{2}\right](\mathrm{OTf})_{2} \quad(\mathbf{1 0})$ by slow vapour diffusion of diethyl ether into an acetonitrile solution of the complex. Crystal structure determination showed a very distorted octahedral geometry for the iron complex (Fig. 6); selected bond lengths and angles are depicted in Table S1. $\dagger$ Two PyProNH ligands coordinate in a meridional fashion around the iron centre, corresponding to the ligand to metal ratio found in the

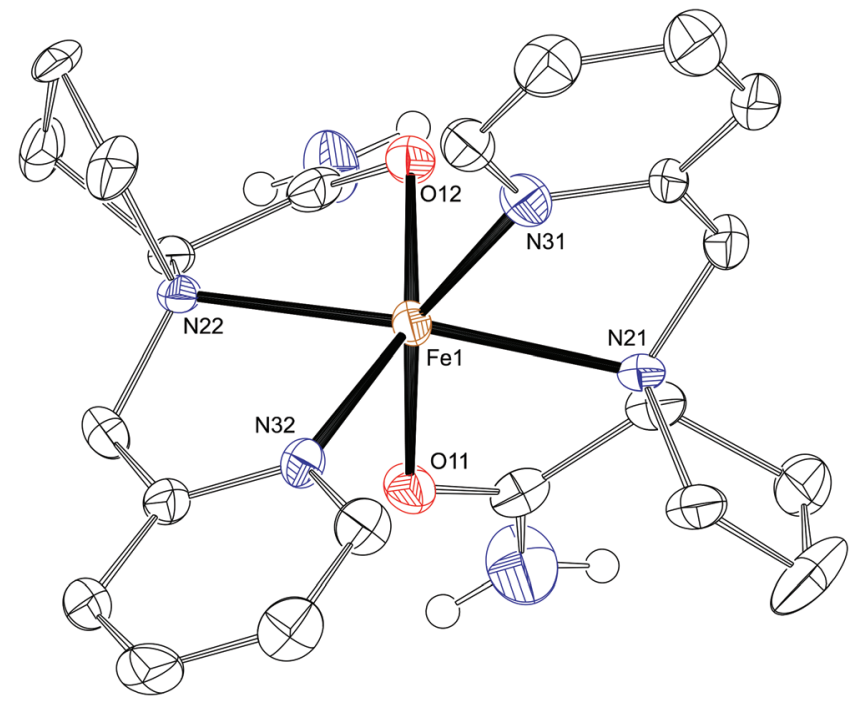

Fig. 6 Displacement ellipsoid plot (50\% probability) of 10; C-H hydrogen atoms and non-coordinated triflate anions are omitted for clarity. 
Job plot (Fig. 4). From each ligand, the nitrogen atoms of the pyridine and the proline ring coordinate to iron, and the tridentate nature of the ligand is complemented by coordination of the carbonyl moiety. The triflate moieties are found as disordered, non-coordinating counter ions. The crystal structure showed furthermore that complex $\mathbf{1 0}$ is involved in a hydrogenbonded one-dimensional chain (ESI Fig. S1 and Table S2†).

The meridional coordination mode of the tridentate ligands is most likely caused by steric reasons and gives rise to a trans orientation of the proline rings; the two $\mathrm{Fe}-\mathrm{O}$ bonds are oriented cis to each other. The Fe-N distances vary between 2.132(5) and 2.197(5) $\AA$, which are typical bond distances for high spin iron(II) complexes. The deviation from ideal octahedral geometry is reflected in the bond angles around iron (angular variance is $257.62 \mathrm{deg}^{2}$ ), which is caused by the geometrical restrictions of the ligands.

\section{Fe-chloride complexes}

The preparation of $1: 1$ iron to ligand complexes using the PyProR ligands 1-8 was envisioned through the use of an iron(II) source that contains coordinating counter ions. Indeed, complexes 12-15 were prepared via the reaction of one equivalent of the corresponding ligand with one equivalent of ferrous chloride in methanol under an inert $\mathrm{N}_{2}$-atmosphere for $1 \mathrm{~h}$. After precipitation with $\mathrm{Et}_{2} \mathrm{O}$, the complexes were isolated as yellow powders in $90-94 \%$ yield (Scheme 3). Complexes 12-15 were stored in an inert atmosphere drybox because of their air sensitivity.

Ferrous chloride complexes $\mathbf{1 6}$ and $\mathbf{1 7}$ derived from the diphenylprolinol ligands 7 and $\mathbf{8}$ were prepared in a similar manner using a solvent mixture of methanol and dichloromethane $(4: 5, \mathrm{v} / \mathrm{v})$ because of solubility reasons. Both complexes were isolated as yellow powders after precipitation in a yield of 90 and 85\%, respectively (Scheme 3). Complexes 16 and $\mathbf{1 7}$ were also stored in an inert atmosphere drybox because of their air sensitivity.

ESI-MS analysis of the chloride complexes 12-17 showed a singly charged parent peak of composition $[\mathrm{Fe}(\mathrm{L})(\mathrm{Cl})]^{+}$in all cases and pointed at the formation of complexes with a metal to ligand ratio of $1: 1$. Elemental analysis corroborated the formation of complexes with an $\left[\mathrm{Fe}(\mathrm{L}) \mathrm{Cl}_{2}\right]$ composition.

For these ferrous chloride complexes, IR spectroscopy is somewhat less informative than in the case of the ferrous
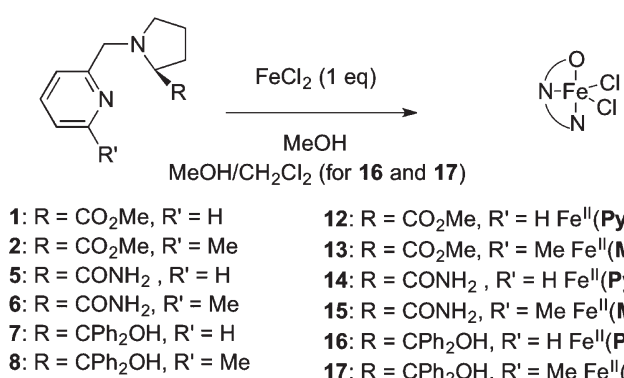

12: $\mathrm{R}=\mathrm{CO}_{2} \mathrm{Me}, \mathrm{R}^{\prime}=\mathrm{H}$ Fe" $($ PyProMe $) \mathrm{Cl}_{2}$ 13: $\mathrm{R}=\mathrm{CO}_{2} \mathrm{Me}, \mathrm{R}^{\prime}=\mathrm{Me} \mathrm{Fe}$ "l(MePyProMe $) \mathrm{Cl}_{2}$ 14: $\mathrm{R}=\mathrm{CONH}_{2}, \mathrm{R}^{\prime}=\mathrm{H}$ Fe"l $\left(\mathrm{PyProNH}_{2}\right) \mathrm{Cl}_{2}$ 15: $\mathrm{R}=\mathrm{CONH}_{2}, \mathrm{R}^{\prime}=\mathrm{Me} \mathrm{Fe}$ "I $\left(\mathrm{MePyProNH}_{2}\right) \mathrm{Cl}_{2}$ 16: $\mathrm{R}=\mathrm{CPh}_{2} \mathrm{OH}, \mathrm{R}^{\prime}=\mathrm{H}$ Fe"l $\left(\mathrm{PyPrOPh}_{2} \mathrm{OH}\right) \mathrm{Cl}_{2}$ 17: $\mathrm{R}=\mathrm{CPh}_{2} \mathrm{OH}, \mathrm{R}^{\prime}=\mathrm{Me} \mathrm{Fe} \mathrm{e}^{\mathrm{Il}}\left(\mathrm{MePyPrOPh}_{2} \mathrm{OH}\right) \mathrm{Cl}_{2}$

Scheme 3 Synthesis of the chloride complexes 12-17. triflate complexes due to the weak intensity of the $\mathrm{Fe}-\mathrm{Cl}$ vibrational peaks. The solid-state IR spectrum of [Fe(PyProMe)$\mathrm{Cl}_{2}$ ] (12) does show a clear vibration band of the carbonyl group at $1697 \mathrm{~cm}^{-1}$. The corresponding vibration of the free ligand is found at $1732 \mathrm{~cm}^{-1}$. This shift in energy clearly indicates the coordination of the carbonyl group to the iron centre. The solution IR spectrum of [Fe(PyProMe $\left.) \mathrm{Cl}_{2}\right]$ in $\mathbf{M e C N}$ shows the carbonyl vibration at $1702 \mathrm{~cm}^{-1}$, which indicates that in solution the carbonyl group remains coordinated to iron.

For the 6-methylpyridine complex [Fe(6-Me-PyProMe) $\left.\mathrm{Cl}_{2}\right]$ (13), the same trend in the vibration of the carbonyl group was observed for the free ligand, the prepared complex and the complex in solution (MeCN). Complexes $\left[\mathrm{Fe}\left(\mathbf{P y P r o N H} \mathbf{N}_{2}\right) \mathrm{Cl}_{2}\right](\mathbf{1 4})$ and $\left[\mathrm{Fe}\left(6-\mathrm{Me}-\mathrm{PyProNH} \mathrm{N}_{2}\right) \mathrm{Cl}_{2}\right]$ (15) showed a carbonyl vibration at 1652 and $1656 \mathrm{~cm}^{-1}$, respectively, in their solid state IR spectra. In the free ligands, these bands are also found at a relatively low energy, which is most likely caused by the intermolecular hydrogen bonding between the carbonyl and the amino groups. For the prolinol complexes $\left[\mathrm{Fe}\left(\mathbf{P y P r o P h} \mathbf{P}_{2} \mathbf{O H}\right) \mathrm{Cl}_{2}\right](\mathbf{1 6})$ and $[\mathrm{Fe}(\mathbf{6}$ Me-PyProPh $\left.{ }_{2} \mathrm{OH}\right) \mathrm{Cl}_{2}$ ] (17) a characteristic broad band around $3060 \mathrm{~cm}^{-1}$ for the $\mathrm{ROH}$ group was observed, which points to coordination of this moiety towards the metal centre.

Magnetic susceptibility measurements in solution using Evans' method ${ }^{25,26}$ showed the formation of high spin $(S=2)$ iron(II) chloride complexes. Detailed spectroscopic characteristics for complexes 12-17 are summarized in Table 1.

\section{Structural features of the Fe chloride complexes in the solid sate (X-ray crystal structures)}

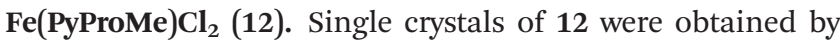
either slow vapor diffusion of ether into a solution of 12 in dichloromethane, or by ether diffusion into a solution of $\mathbf{1 2}$ in methanol. These crystallization conditions lead to different crystal forms in which 12 adopts different coordination geometries (Fig. 7).

From a non-coordination solvent, complex 12a crystallizes in a very distorted five-coordinated geometry, which cannot be

Table 1 Spectroscopic properties of complexes 12-17

\begin{tabular}{|c|c|c|c|c|c|}
\hline Complex & $\begin{array}{l}\mathrm{C}=\mathrm{O} \\
\text { vibration } \\
\text { free ligand } \\
\left(\mathrm{cm}^{-1}\right)\end{array}$ & $\begin{array}{l}\mathrm{C}=\mathrm{O} \\
\text { vibration } \\
\text { complex } \\
\left(\mathrm{cm}^{-1}\right)\end{array}$ & $\begin{array}{l}\mathrm{UV}^{-V_{i s}}{ }^{a} \\
(\mathrm{~nm})\end{array}$ & $\begin{array}{l}\text { ESI-MS } \\
(m / z) \\
{[\mathrm{M}-\mathrm{Cl}]^{+}}\end{array}$ & $\begin{array}{l}\text { Evans } \\
\mu_{\text {eff }}\left(\mu_{\beta}\right)\end{array}$ \\
\hline 12 & 1732 & 1697 & $\begin{array}{l}\text { 291(866), } \\
363(501)\end{array}$ & 311.025 & 4.62 \\
\hline 13 & 1732 & 1687 & $\begin{array}{l}207(9910), \\
267(4282), \\
369(338)\end{array}$ & 325.041 & 5.07 \\
\hline 14 & 1668 & 1652 & $385(469)$ & 296.026 & 4.33 \\
\hline 15 & 1625 & 1657 & $385(456)$ & 310.040 & 5.10 \\
\hline 16 & & & $\begin{array}{l}255(7096) \\
292(5319)\end{array}$ & 425.091 & 4.88 \\
\hline 17 & & & $\begin{array}{l}\text { 205(21 889), } \\
261(7282), \\
316(4139)\end{array}$ & 449.106 & 5.23 \\
\hline
\end{tabular}

${ }^{a}$ Extinction coefficients $\left(\mathrm{M}^{-1} \mathrm{~cm}^{-1}\right)$ are given in parentheses after each feature. 


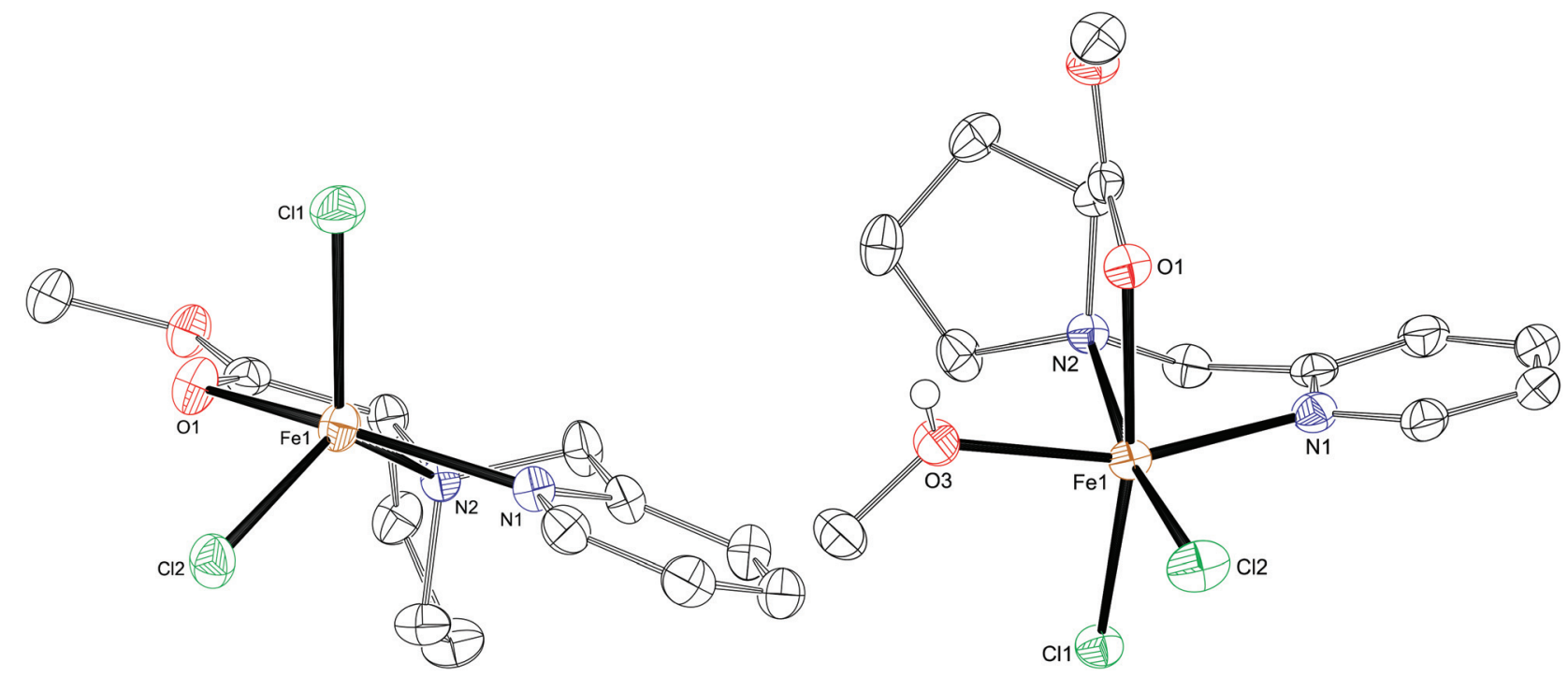

Fig. 7 Molecular structures of complex 12 crystallized from a dichloromethane solution (12a, left) or a methanol solution (12b, right). Displacement ellipsoid plot (50\% probability); $\mathrm{C}-\mathrm{H}$ hydrogen atoms are omitted for clarity.

described by a Berry pseudorotation pathway. The two largest angles at $\mathrm{Fe} 1$ are 149.78(6) (N1-Fe1-O1) and 126.96(5) ${ }^{\circ}$ (Cl1-Fe1-Cl2), while one would expect $180^{\circ} / 120^{\circ}$ for an ideal trigonal bipyramid and $150^{\circ} / 150^{\circ}$ for a square pyramid.

Using a coordinating solvent like methanol, the complex crystallizes in an octahedral geometry with a facial coordination mode of the PyProMe ligand. In the octahedral geometry a methanol solvent molecule is coordinated trans to the pyridine ring. Selected bond lengths and angles of 12a and 12b are depicted in Table S3. $\dagger$

The observed $\mathrm{Fe}-\mathrm{N}$ bond lengths are all in agreement with high spin $(S=2)$ iron(II) complexes. The bond length towards $\mathrm{Cl} 1$ in 12b is much longer than the other $\mathrm{Fe}-\mathrm{Cl}$ bond lengths. $\mathrm{Cl} 1$ is the acceptor of an intermolecular hydrogen bond with the hydroxyl atom of the coordinated methanol of a neighbouring complex as a hydrogen bond donor (ESI Fig. S2 and Table S4†).

$\mathbf{F e}(6-\mathrm{Me}-\mathrm{PyProMe}) \mathrm{Cl}_{\mathbf{2}}$ (13). Crystals of $\mathbf{1 3}$ suitable for X-ray diffraction were obtained by slow vapour diffusion of ether into a solution of $\mathbf{1 3}$ in methanol. Despite the presence of the coordinating solvent methanol, the crystal structure of $\mathbf{1 3}$ shows a five-coordinated iron centre (Fig. 8) and is therefore similar to 12a (from $\mathrm{CH}_{2} \mathrm{Cl}_{2}$ ) and not to $\mathbf{1 2 b}$ (from $\mathrm{MeOH}$ ). Again, the coordination polyhedron of $\mathbf{1 3}$ is very distorted and does not follow a Berry pseudorotation pathway. The largest angles at $\mathrm{Fe} 1$ are 153.71(6) (N1-Fe1-O1) and 127.01(2) (Cl1-Fe1-Cl2).

The observation that complex 13 does not pick up a methanol molecule in its coordination sphere upon crystallization from methanol most likely arises from the presence of the methyl group at the 6-position of the pyridine ring in 6-MePyProMe. This methyl group provides some steric bulk and seems to prevent the rearrangement of the 6-Me-PyProMe ligand from a mer to a fac coordination mode by blocking the concomitant rearrangement of the two chloride ligands.

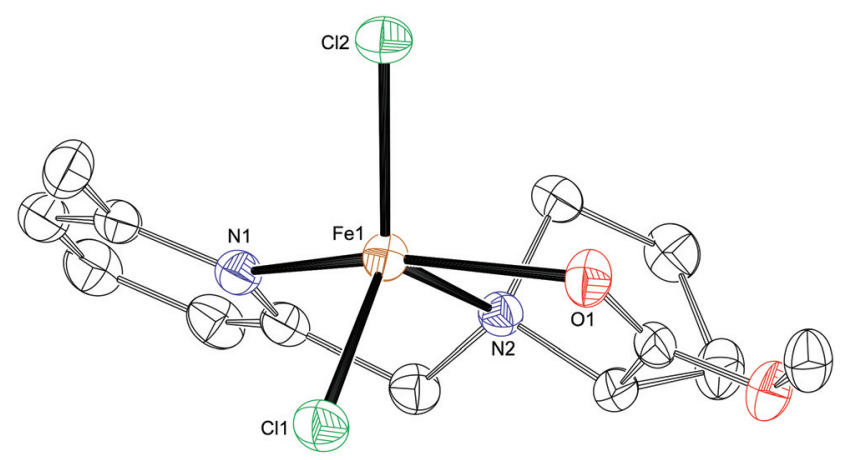

Fig. 8 Molecular structure of complex 13 crystallized from a methanol solution. Displacement ellipsoid plot (50\% probability); all hydrogen atoms are omitted for clarity.

The methyl group is probably also the reason for the larger $\mathrm{Cl}-\mathrm{Fe}-\mathrm{Cl}$ angle in $13\left(127.01(2)^{\circ}\right)$ compared to 12a (113.01(2) $)$. Selected bond lengths and angles for $\mathbf{1 3}$ are shown in Table S5. $\dagger$

$\mathrm{Fe}\left(\mathrm{PyProNH}_{2}\right) \mathrm{Cl}_{2}(\mathbf{1 4})$ and $\mathrm{Fe}\left(6-\mathrm{Me}-\mathrm{PyProNH}_{2}\right) \mathrm{Cl}_{2}$ (15). Crystals suitable for X-ray analysis were obtained by slow vapor diffusion of ether into an acetonitrile solution of $\mathbf{1 4}$ and a methanol solution of complex 15. Compound $\mathbf{1 4}$ crystallizes in an octahedral geometry with a facial coordination of the PyProNH $_{2}$ ligand and with the additional coordination of an acetonitrile molecule (Fig. 9). The acetonitrile ligand is coordinated trans to the proline nitrogen, while in complex 12b the methanol ligand is coordinated trans to the pyridine nitrogen. The crystal structure also showed that complex $\mathbf{1 4}$ is able to form a hydrogen-bonded two-dimensional network in the crystallographic $a, b$-plane (ESI Fig. S3 and Table S7 $\dagger$ ). On the other hand compound $\mathbf{1 5}$ was obtained as a five-coordinated iron complex with a square-pyramidal geometry $(\tau=0.28)^{27}$ (Fig. 9). The basal plane is formed by the tridentate ligand and 

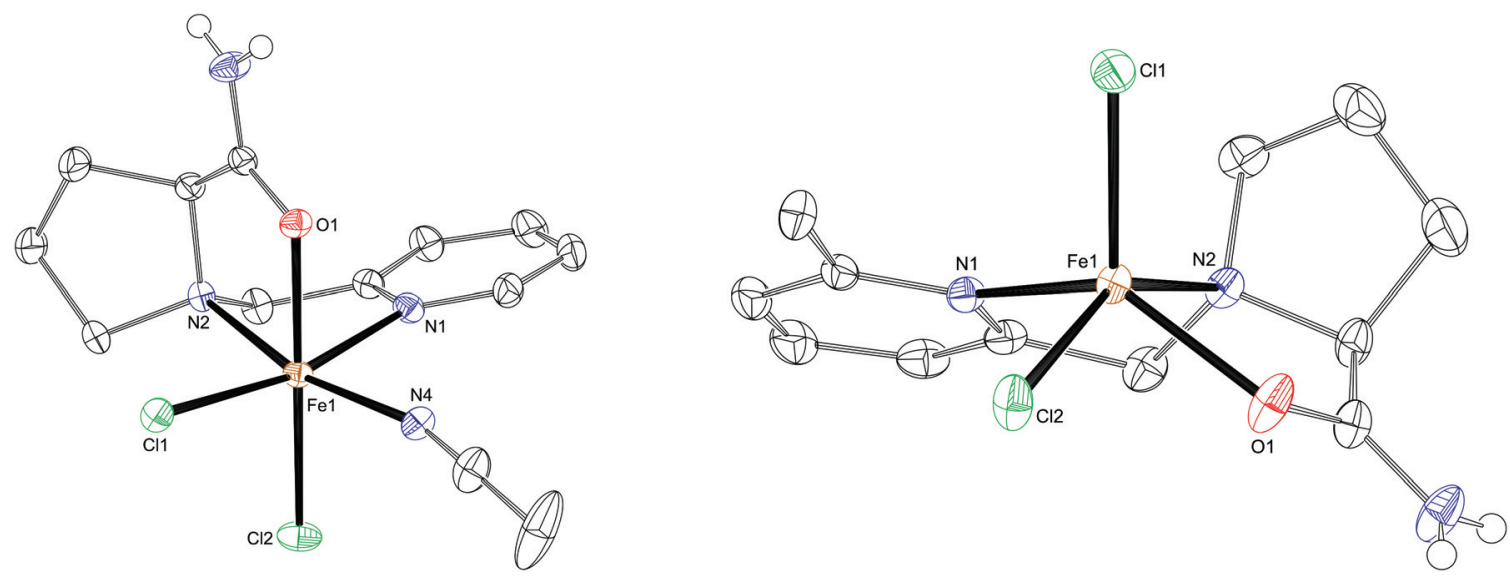

Fig. 9 Molecular structures of complex 14 crystallized from an acetonitrile solution (left) and complex 15 crystallized from a methanol solution (right). Displacement ellipsoid plot (50\% probability); $\mathrm{C}-\mathrm{H}$ hydrogen atoms are omitted for clarity.

the chlorine atom $\mathrm{Cl} 2$. The iron centre Fe1 is $0.73 \AA$ above this plane. The largest angles at Fe1 are 147.29(3) and 130.66(4) ${ }^{\circ}$. The amide group of complex 15 is involved in a one-dimensional hydrogen-bonding network towards the chloride atoms of neighbouring complexes (ESI Fig. S4 and Table S8†). Probably also in this case, just like for complex 13, the presence of the methyl group on the pyridine ring prevents the coordination of a solvent molecule, giving rise to a five coordinated iron center.

The proline ring in both structures has the envelope conformation, for complex 14 (cosform 0.966, sinform 0.034) ${ }^{28}$ and for complex 15 (cosform 0.804, sinform 0.196). ${ }^{27}$ Selected bond lengths and angles of complexes 14 and 15 are depicted in Table S6. $\dagger$

The $\mathrm{Fe}-\mathrm{O}$ bond lengths of these two complexes are significantly shorter than the other reported $\mathrm{Fe}-\mathrm{O}$ bond lengths. This difference can be explained by the presence of the amide group. The carbonyl group in an amide bond has a higher partial negative charge compared to the carbonyl group in an ester bond due to the lower electronegativity of nitrogen compared to oxygen. This difference causes the amide carbonyl group to bind more strongly to the iron centre.

$\mathrm{Fe}\left(\mathrm{PyProPh}_{2} \mathrm{OH}\right) \mathrm{Cl}_{2}$ (16) and $\mathrm{Fe}\left(6-\mathrm{Me}-\mathrm{PyProPh}_{2} \mathrm{OH}\right) \mathrm{Cl}_{2}$ (17). For the last two complexes crystals suitable for X-ray analyses were obtained by diffusion of ether into a dichloromethane solution of the corresponding complex. Fig. 10 shows the two molecular structures. For both complexes 16 and 17, two independent residues (res 1 and res 2) are present in the asymmetric unit. Both complexes also turned out to form hydrogen-bonded dimers between the two independent molecules (ESI Fig. S5 and Table S10† for complex 16 and Fig. S6 and Table S11† for complex 17).

In 16, both independent molecules have a five-coordinated iron centre with a geometry between square pyramidal and trigonal bipyramidal $(\tau=0.43 / 0.37) .{ }^{27}$ The two independent molecules in $\mathbf{1 7}$ have a square pyramidal geometry $(\tau=0.28$ / $0.24)^{27}$ with the basal plane formed by the tridentate ligand and one chlorine. The iron centre is $0.82 / 0.81 \AA$ above this plane. Selected bond lengths and angles for both residues of complexes $\mathbf{1 6}$ and $\mathbf{1 7}$ are depicted in Table S9. $\dagger$
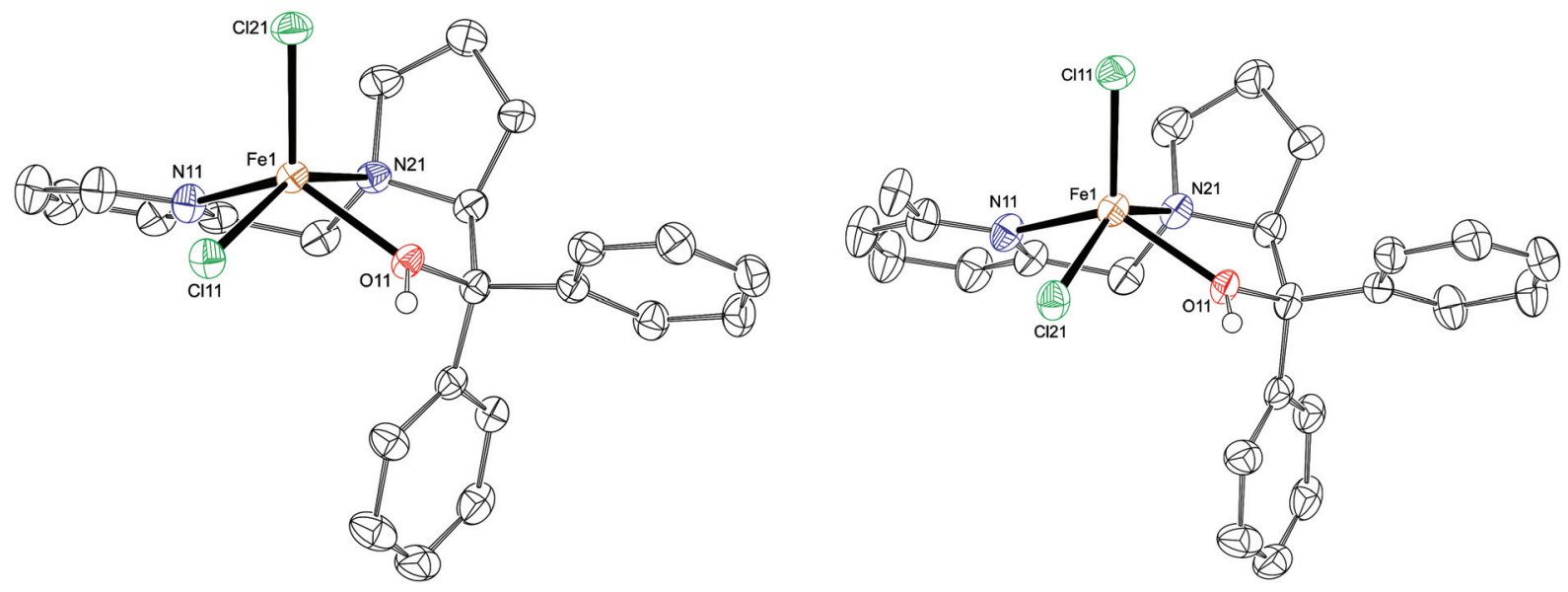

Fig. 10 Molecular structures of complexes 16 and 17. Displacement ellipsoid plot (50\% probability); C-H hydrogen atoms and the co-crystallized $\mathrm{CH}_{2} \mathrm{Cl}_{2}$ solvent molecule in 16 are omitted for clarity. For both structures, only one of two independent residues is shown. 


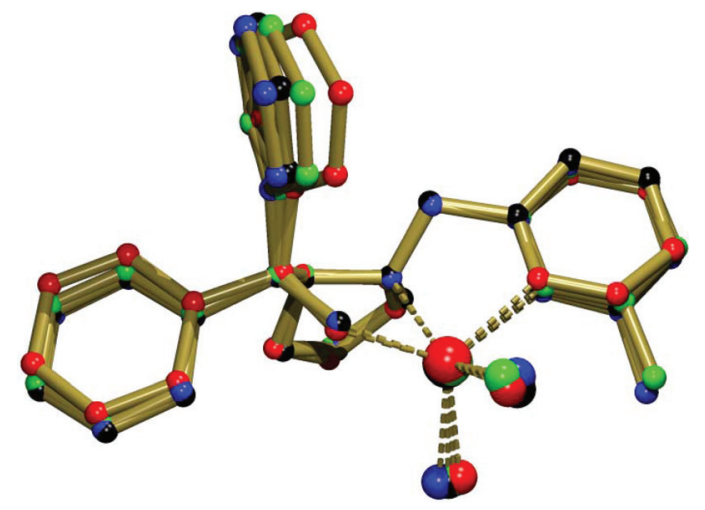

Fig. 11 Quaternion fit of all residues in the crystals of 16 and 17 (16: red (res 1) and black (res 2); 17: green (res 1) and blue (res 2)).

The bond lengths differ slightly between the two complexes. The bond length Fex-N1x is slightly longer for complex 17, which also in this case may be due to the presence of the methyl group in the sixth position on the pyridine ring. Furthermore, the angle between the two chloride atoms is larger for the complex with the methyl group at the sixth position of the pyridine ring. For comparison, a quaternion plot of the different residues in crystals of $\mathbf{1 6}$ and $\mathbf{1 7}$ is presented in Fig. 11, which clearly shows the similarity of the four structures. The most apparent differences are the orientation of the two phenyl rings of the diphenylprolinol moiety and the Cl$\mathrm{Fe}-\mathrm{Cl}$ angle. Overall the pyridine methyl group has no large structural influence in this case.

\section{Oxidation catalysis}

Iron(II) complexes 9-17 were tested as catalysts for the epoxidation of alkene substrates. For the catalytic screening acetonitrile was chosen as a solvent and hydrogen peroxide was used as a sacrificial oxidant. A ratio between catalyst, oxidant and substrate of $1: 100: 500$ (oxidant limiting conditions) was used during these screenings (Scheme 4). In total four different benchmark substrates were used, cyclooctene, 1-octene, styrene and trans-beta-methylstyrene. trans-Betamethylstyrene was used to examine the enantio-inducing ability of the chiral iron(II) complexes. Product formation was monitored by GC after 1 and $3 \mathrm{~h}$, and after 1 night.

Table 2 shows the conversion data (TON in epoxide/benzaldehyde) in the reactions with the triflate complexes 9-11 derived from PyProMe, $\mathbf{P y P r o N H} \mathbf{N}_{2}$ and $\mathbf{P y P r o P h} \mathbf{P}_{2} \mathbf{O H}$. Among these complexes, 10 showed the highest activity towards all four substrates, while complex $\mathbf{9}$ and in particular the more bulky complex 11 showed poor activities. As it turned out, 1-octene is not a suitable substrate for these complex systems, as there is hardly any conversion to the epoxide product. In the best case, for complex 10, a conversion towards the epoxide of $3.3 \%$ is obtained based on the amount of added hydrogen peroxide.

The highest conversion to epoxide products was observed with trans-beta-methylstyrene, although no appreciable

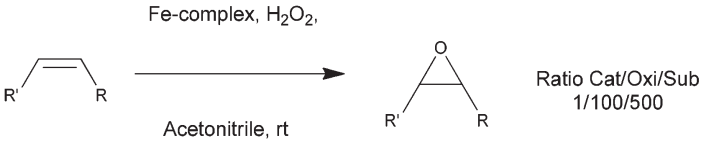

Scheme 4 General representation of catalytic conditions.

enantioselectivity was found. In the best case a conversion towards the epoxide of $35 \%$ is reached based on the amount of oxidant used, with the total productive consumption of hydrogen peroxide of $51 \%$ (formation of epoxide and benzaldehyde). Benzaldehyde formation was observed both in the reactions with styrene and trans-beta-methylstyrene. In fact, in the case of $\mathbf{9}$ and $\mathbf{1 1}$ more benzaldehyde than epoxide is formed out of styrene after 1 night (9 equiv. for 9 and 4.5 equiv. for 11). Complex 10 produces an equal amount of epoxide and benzaldehyde after 1 night. In the reactions with trans-beta-methylstyrene the epoxide is the predominant product after 1 night. Overall, the activity of these triflate complexes is rather poor, except perhaps for complex 10 in combination with styrenes. The low activity of the complexes is likely caused by the fact that these complexes are coordinatively saturated; it seems that at least one dative bond needs to be broken before the complexes can interact with either the substrate or the oxidant.

The chloride complexes 12-17 showed an overall higher reactivity profile compared to the triflate complexes 9-11 in the oxidation reactions (Table 3). At the same time, several trends are rather similar amongst the two series of complexes. In all cases, aliphatic olefins and in particular external olefins (1-octene) are converted in only a small number of turnovers, while styrenes give higher and in some cases good turnover numbers.

In addition, the amide-appended complexes $\mathbf{1 0}$ and $\mathbf{1 5}$ give the highest activities in these series, while the most bulky complexes 11, 16, and 17 give the lowest activities. For transbeta-methylstyrene, amide complex 15, [Fe(6-Me-PyProNH $\mathbf{N H}_{2}$ $\mathrm{Cl}_{2}$ ], gives 50 turnovers in epoxide formation, which corresponds to $50 \%$ productive $\mathrm{H}_{2} \mathrm{O}_{2}$ consumption. Significant benzaldehyde formation was also observed with styrene substrates in the case of complexes 12-17 (Table 3).

In order to provide an overview of the overall activity of the chloride complexes, the cumulative formation of epoxides and aldehydes as a measure for productive $\mathrm{H}_{2} \mathrm{O}_{2}$ consumption is shown in Fig. 12. The graph clearly shows the overall effect of the 6-Me-pyridine substituent on the catalytic activity. For 12 and 13 only minor changes are observed, whereas for $\mathbf{1 6}$ and 17 reactivity clearly goes down. In contrast, for amide complexes $\mathbf{1 4}$ and $\mathbf{1 5}$ inclusion of a methyl-substituent leads to a substantial increase in reactivity. Clearly, the highest activity is obtained for complex 15, with a maximum of $65 \%$ productive $\mathrm{H}_{2} \mathrm{O}_{2}$ conversion with methylstyrene. Also for this series of catalysts, a mediocre enantioselectivity was found in the epoxide formation out of styrenes. No attempts were made to further optimize these ee values. 
Table 2 Oxidation of alkenes catalysed by complexes $9-11^{a}$

$\mathrm{TON}^{b}$

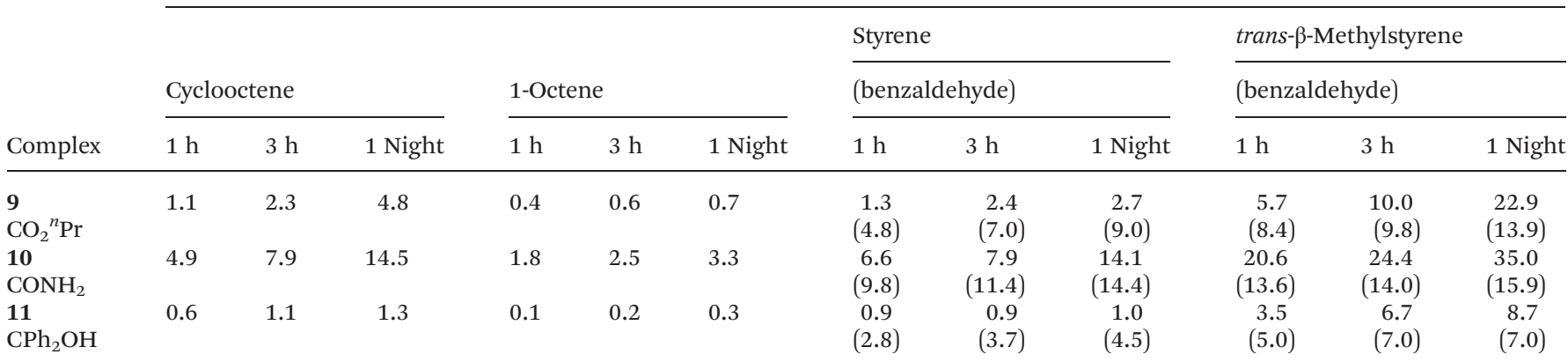

${ }^{a}$ Reaction conditions: $0.5 \mathrm{~mL}$ of $700 \mathrm{mM} \mathrm{H}_{2} \mathrm{O}_{2}$ solution in acetonitrile $\left(0.35 \mathrm{mmol}, 100\right.$ eq., diluted from $35 \%$ aqueous $\left.\mathrm{H}_{2} \mathrm{O}_{2}\right)$ was slowly added over $30 \mathrm{~min}$ to a stirred solution of $3 \mathrm{~mL}$ acetonitrile containing catalyst $(3.5 \mu \mathrm{mol})$ and substrate $(1.75 \mathrm{mmol})$ at ambient temperature, stirring was continued for another $30 \mathrm{~min}$. After 1 hour from the start internal standard was added $(10 \mu \mathrm{L}$, cyclooctene: 1,2-dibromobenzene, all other substrates: bromobenzene) and the first samples were taken and analyzed by GC. ${ }^{b}$ Moles of product/moles of catalyst.

Table 3 Oxidation of alkenes catalyzed by complexes $12-17^{a}$

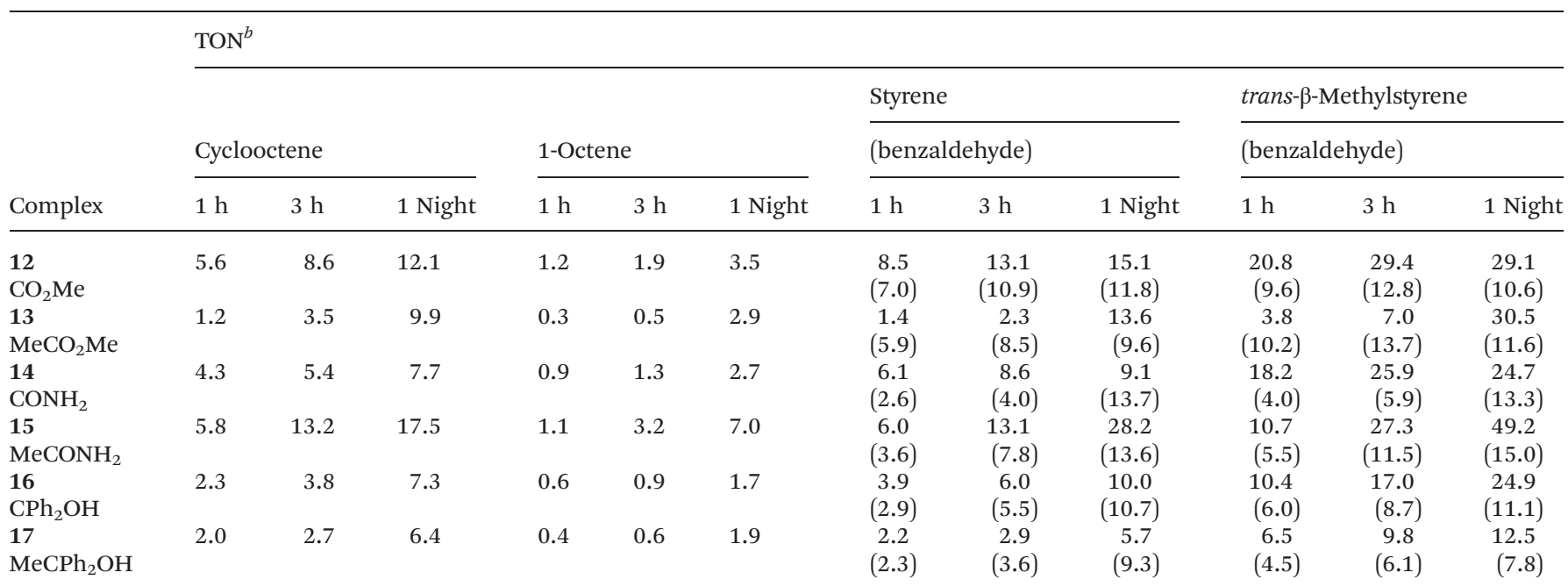

${ }^{a}$ For reaction conditions see Table $2 .{ }^{b}$ Moles of product/moles of catalyst.

\section{Discussion}

In the present investigations we have explored the coordination chemistry of a series of simple pyridinyl prolinate and pyridinyl diphenylproline ligands with respect to $\mathrm{Fe}(\mathrm{II})$. Whereas the parent ligand of the series reported here (S)-methyl1-(pyridin-2-ylmethyl)pyrrolidine-2-carboxylate (PyProMe) has been studied by Paine et al. in relation with iron-mediated catechol oxidation, ${ }^{20}$ the current extended series of pyridinyl proline ligands (RPyProR) allows for a more general description of the coordination properties of this ligand family. The specific interest in these ligands combines the ease of synthesis of these chiral ligands and their anticipated mimicry of the 2-His-1-carboxylate facial triad coordination mode as found in certain mono-nuclear non-heme iron enzymes. Our synthetic efforts have resulted in a full structural characterization of most of the reported $\mathrm{Fe}(\mathrm{II})$ complexes and

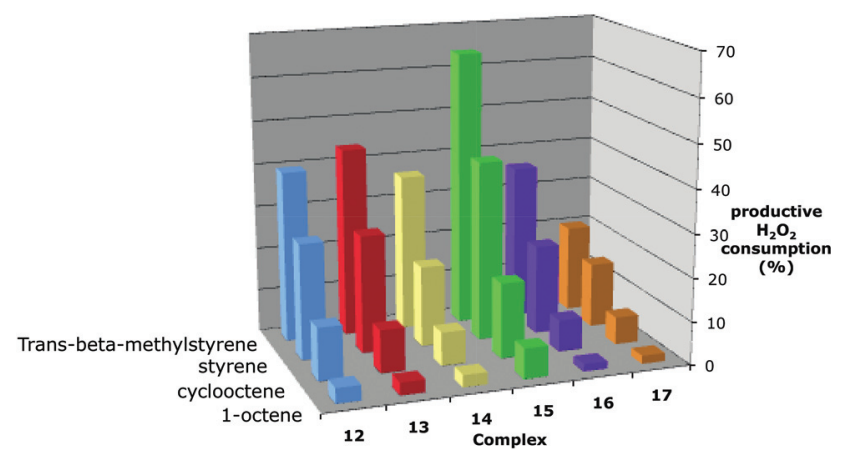

Fig. 12 Productive consumption of an oxidant after 1 night for complexes 12-17.

show the coordinative flexibility of the N,N,O pyridinyl proline fragment acting either as a meridional or as a facial ligand. 
Closed-shell, octahedral structures of the type $\left[\mathrm{Fe}(\mathrm{L})_{2}\right]^{2+}$ were formed when iron triflate was used as the iron source. This is a rather common observation for tridentate ligands and has also been observed for related tridentate ligands of the N,N,O type. In our earlier studies on BAIP and BAIP ${ }^{\mathrm{R}}$ type ligands, the formation of similar octahedral closed-shell structures was observed in cases where non-coordinating counter ions were used, albeit that in these cases the ligands coordinate in a facial rather than in the meridional manner to iron like observed for complex $\mathbf{1 0} .^{15 c, 29}$

In particular when anionic N,N,O ligands are used, the formation of octahedral bis-ligand complexes is difficult to avoid. Attempts to form discrete $[\mathrm{Fe}(\mathrm{II})(\mathrm{L}) \mathrm{X}]$ or $\left[\mathrm{Fe}(\mathrm{III})(\mathrm{L}) \mathrm{X}_{2}\right]$ complexes derived from the family of BAIP-ligands have proven difficult so far. In most reported cases the thermodynamic $\left[\mathrm{Fe}(\mathrm{L})_{2}\right]^{0 / 1+}$ complexes did form. Burzlaff and co-workers also reported on their difficulties in synthesizing mono-ligand complexes derived from the bis(pyrazolyl)proprionate ligand family. Ultimately, they succeeded in synthesizing $\left[\mathrm{Fe}(\mathrm{L}) \mathrm{Cl}_{3}\right]^{-}$in which iron is in the oxidation state $3+{ }^{12}$ The major differences between the RPyProR ligands and the BAIP as well as the bis(pyrazolyl)proprionate ligand families are the predisposed facial coordination modes of the latter ligands and their anionic nature in comparison to the neutral PyPro ligands.

Using $\mathrm{FeCl}_{2}$ as the source of iron in combination with a PyPro ligand leads to the formation of discrete $\left[\mathrm{Fe}(\mathrm{L}) \mathrm{Cl}_{2}\right]$ complexes that have a penta-coordinated iron centre. For complexes 15-17 the geometry would at best be described as square pyramidal ( $\tau$ values vary from 0.24 to 0.45 ). Following the square pyramidal description the PyPro ligands coordinate to iron as a N,N,O meridional ligand in these cases, positioning the two chloride ligands in 'equatorial' positions. Examples of discrete square pyramidal structures in non-heme iron chemistry include complexes derived from pyridine(bisimine) ligands. ${ }^{30,31}$ Other examples of meridionally coordinated N,N,O ligands are reported with cobalt, zinc and copper. $^{32-34}$

Detailed analysis of the 5-coordinated structures reported here (7 in total) shows that none of these structures obeys exactly the Berry pseudo-rotation trajectory (ESI Table S12 $\dagger$ ). The deviation is particularly large for complexes 12 and 13, which is why $\tau$ values would not properly describe their geometry. This again shows that the coordination geometry of these complexes is ill-defined and can, accordingly, actually not be labelled as square pyramidal. An analysis of the CSD-database ${ }^{35}$ revealed 14 other 5 -coordinated $\mathrm{FeCl}_{2}$ complexes bearing an N,N,O ligand. ${ }^{36}$ of these complexes also none obeys exactly the Berry trajectory. A graphical representation of the 14 structures found in the CSD-database and our 7 structures reported here is depicted in the ESI (Graph S1). $\dagger$ Vahrenkamp and co-workers have earlier noticed this feature in 5-coordinated $\mathrm{Zn}$ (II) complexes and have proposed an adapted description of the Berry trajectory in these systems. ${ }^{37}$ The current set of Fe(II) complexes is limited in number and does not allow for a similar analysis at this stage. Current efforts in our lab involve the expansion of the set of 5-coordinated $\mathrm{FeCl}_{2}$ complexes in order to arrive at a more detailed structural description of such complexes.

The coordination flexibility of the PyPro ligands is shown by the complexes that form when their 5-coordinated complexes are crystallized from coordinating solvents like methanol or acetonitrile. In such solvents, these complexes accommodate one solvent molecule in the coordination sphere of iron and, accordingly, form octahedral complexes of the type $\left[\mathrm{Fe}(\mathrm{L})(\right.$ solv $\left.) \mathrm{Cl}_{2}\right]$. In these cases the coordination geometry of the RPyProR ligand becomes facial. The coordination of solvent molecules is only observed in complexes that contain a PyPro ligand without an unsubstituted pyridine moiety. Introduction of a methyl group at the 6-position of this moiety prevents the coordination of solvent molecules at the cis-position with respect to the pyridine $\mathrm{N}$-donor, most likely due to steric constraints. Solvent coordination at the trans-position is also prevented because the size of the methyl substituent prevents the reorientation of the chloride ligands, i.e. positioning of the $\mathrm{Fe}-\mathrm{Cl}$ vector within the plane defined by the pyridine ring is not possible. Where the pyridine 6-position in nitrogen ligands is often used to steer substrate approach to the metal center $^{38}$ and the electronics at the metal (spin state), ${ }^{8 b}$ inclusion of a substituent at this position in the RPyProR ligand framework prevents a meridional to facial ligand coordination change and locks the RPyProR framework in a meridional conformation.

All prepared complexes 9-17 were tested in the catalytic oxidation of different alkenes using hydrogen peroxide as the oxidant. During the catalytic reactions oxidant limiting conditions were used to allow putative short-live oxygenated metal species to be trapped rapidly by the excess of substrate. It turned out that the triflate complexes perform far less compared to the chloride-based complexes. This can be explained by the fact that the triflate complexes are closed-shell complexes with a fully occupied octahedral coordination sphere around iron. These complexes can, therefore, only react via inner-sphere pathways with external reagents such as alkene substrates or oxidants after one or more existing coordination bonds are broken. The chloride complexes turned out to be much more reactive. Several of the crystal structures of these complexes nicely show how solvent molecules can be accommodated in their coordination sphere to obtain six-coordinate complexes. The formation of oxygenated complexes of the type $\left[\mathrm{Fe}(\mathrm{L})(\mathrm{Cl})_{2}(\mathrm{ox})\right]$ is therefore not restricted due to the lack of coordination sites.

The observation of the lower activity of the triflate complexes is also somewhat surprising. We have earlier reported that related coordinatively saturated $\left[\mathrm{Fe}(\text { BAIP })_{2}\right]^{2+}$ complexes are active as epoxidation/dihydroxylation catalysts and have postulated that open coordination sites in these systems may form by means of ester moiety dissociation. ${ }^{15 c}$ In addition, the $\left[\mathrm{Fe}(\mathrm{Ph}-\mathrm{DPAH})_{2}\right]^{2+}$ system that was studied by Que et al. has similar coordination features and at the same time is very active in the dihydroxylating of olefins (TONs of 8 are obtained, ratio catalyst: oxidant: substrate $1: 10: 1000){ }^{13}$ In this case the authors have assumed that full dissociation of 
one of the facial N,N,O ligands takes place prior to any catalytic turn-over. Given the lower turn-over numbers of the PyProderived iron triflate complexes ligand dissociation does not seem to take place readily for these complexes and accordingly TONs are lower.

The overall structure of the RPyProR ligands has a distinct effect on the catalytic activity of their complexes. Complexes derived from bulky diphenylprolinol ligands gave the lowest activities, both in the case of the triflate as well as the chloride complexes and for all substrates. A combination of alcohol instead of ester or amide coordination and enhanced steric bulk could lead to a less electron-rich metal centre (electronic effect) and a less favourable olefin substrate attack on the oxygenated active species (steric effect). In all cases, complexes derived from amide-appended RPyProR ligands gave the better catalysts, i.e. higher productive consumption of $\mathrm{H}_{2} \mathrm{O}_{2}$ was found. The higher activity of these complexes may be explained by the stronger $\mathrm{Fe}-\mathrm{O}$ bonds that are formed by the amide ligands, which could lead to enhanced catalyst lifetimes. On the other hand, the short $\mathrm{Fe}-\mathrm{O}$ bond lengths to the amide moieties indicate an enhanced electron donation, which will lead to more electron-rich Fe-centres and, in turn, to lower oxidation potentials. Finally, the amino groups of the primary amide may have a stabilizing effect on putative highvalent iron-oxygen intermediates by means of acting as a hydrogen bond donor. Similar effects were recently found for amide BAIP ${ }^{\mathrm{R}} \mathrm{Fe}(\mathrm{II})$ complexes. $^{29}$

Concerning the reactivity of the RPyProR systems towards different olefin substrates, it is clear that these show a higher reactivity towards the more electron-deficient styrenes than to the more electron-rich aliphatic olefins. This observation seems to point to a nucleophilic nature of the active species in the oxidations. This seems to make sense given the neutral nature of the more reactive $\mathrm{Fe}(\mathrm{II}) \mathrm{Cl}_{2}$ complexes and of their putative high-valent intermediates, in particular in the presence of coordinating chlorides. The comparison of the relative reaction rates of a series of para-substituted styrene substrates did not show an appreciable difference in the reaction rate. While this observation does not prove the nucleophilic nature of the active species, it may indicate that other reaction steps besides substrate attack are involved in determining the overall reaction rate. In the oxidation experiments with the pro-chiral trans-beta-methylstyrene substrate no appreciable enantioselectivity was observed. This can probably be rationalized by the involvement of a radical-based reaction pathway, which tends to result in racemic product distributions. This assumption is corroborated by the large extent of benzaldehyde formation in the oxidation of styrenes by the PyPro systems. On the other hand, the use of trans-beta-methylstyrene as the substrate did result in the highest TONs for these systems. With amide complex 15, a useful conversion of the oxidant towards the epoxide of almost $50 \%$ was reached, and an overall productive conversion of the oxidant of almost $65 \%$ was found.

Finally, the role of the substitution of the pyridine moiety in the PyPro ligands on their reactivity may be pointed out. In the case of the chloride complexes 12-17, the reactivity remains about equal between $\mathbf{1 2}$ and 13; it increases considerably between 14 and 15, but decreases between 16 and 17. Although there is no clear trend, it seems that complexes without the 6-methyl substituent on pyridine have a higher initial activity compared to the complexes with the methyl group (Table 3). On the other hand, complexes bearing the 6-methyl group do stay active over the whole course of the reaction. This reactivity difference can be explained by assuming a longer lifetime of species involved in the catalytic cycle for the complexes with the methyl group due to steric congestion. The fact that complexes derived from the methyl-substituted ligands do not accommodate a solvent molecule as the sixth ligand could also implicate a higher barrier for the formation of six-coordinate oxygenated intermediates for these complexes. This would either suggest that these systems operate via a different pathway or that different kinetics are at play within a similar pathway.

Few other Fe-based catalysts based on a mixed N,N,O ligand manifold, in particular those based on proline, are known to perform the epoxidation of alkenes using $\mathrm{H}_{2} \mathrm{O}_{2}$. Examples include the BAIP and Ph-DAPH systems (vide supra). Paine et al. reported on a study using the parent ligand (PyProMe) in relationship with iron-catalyzed catechol oxidation instead of the epoxidation of alkenes. ${ }^{20}$ Beller and coworkers reported in 2007 on the use of ligands derived from the L-proline backbone. ${ }^{39}$ These ligands were used in the epoxidation of aromatic alkenes (trans-stilbene) and gave for the first time ee's above $20 \%$. Unfortunately no reactions were done on non-aromatic alkenes. We have previously reported on the use of iron complexes derived from bis-proline substituted pyridine ligands for the oxidation of alkenes with hydrogen peroxide as an oxidant. ${ }^{22}$ These complexes showed a low activity towards the epoxidation of various alkenes.

\section{Conclusions}

In conclusion, we have developed a series of readily available chiral tripodal N,N,O ligands derived from proline. The structural characterization of several Fe(II)complexes has shown that these ligands can adopt a meridional or a facial coordination mode in 6-coordinated complexes. On the other hand, the 5-coordinated complexes show ill-defined geometries that do not obey a Berry-type description. Depending on the size and nature of the substituents at both the proline and at the pyridine ring, the coordination mode of these ligands may change upon binding of a solvent molecule. This allows for the formation of complexes of the type $\left[\mathrm{Fe}(\mathrm{L})(\mathrm{solv}) \mathrm{Cl}_{2}\right]$, where $\mathrm{L}$ is a facial and neutral N,N,O ligand. The further development of such complexes is of interest in modelling the features of the 2-His-1-carboxylate facial triad found in mono-nuclear non-heme iron enzymes.

The use of iron complexes derived from the PyPro ligands results in reasonable turnover numbers for both epoxide and benzaldehyde products, albeit no substantial enantioselectivity 
has been observed thus far. These results may be used as guidelines in the further development of the bio-inspired nonheme iron oxidation catalyst based on cheap chiral building blocks.

\section{Experimental section}

General

Air-sensitive organic reactions and reactions with metal salts were carried out under an inert, $\mathrm{N}_{2}$ atmosphere using standard Schlenk techniques. Solvents were dried and distilled before use. Chemicals were either commercially obtained and used as received or reproduced from the literature. ${ }^{1} \mathrm{H}$ and ${ }^{13} \mathrm{C} \mathrm{NMR}$ spectra were recorded on a Varian 400 spectrometer at $400 \mathrm{MHz}$ and $100 \mathrm{MHz}$, respectively, operating at $25^{\circ} \mathrm{C}$. Infrared spectra were recorded with a Perkin-Elmer Spectrum One FT-IR instrument. Solution IR measurements were recorded with a Mettler Toledo ReactIR ${ }^{\mathrm{TM}} 1000$ spectrometer with a SiComp ${ }^{\mathrm{TM}}$ probe under a $\mathrm{N}_{2}$ atmosphere. ESI-MS was measured on a Waters LCT Premier XE. UV-Vis spectra were recorded on a Varian Cary 50. Solution magnetic moments were determined by the Evans' NMR method in acetone- $d_{6}$-cyclohexane $(95 / 5 \mathrm{v} / \mathrm{v})$ or in acetonitrile- $d_{3}$-cyclohexane $(95 / 5 \mathrm{v} / \mathrm{v})$ at $25{ }^{\circ} \mathrm{C} .^{25,26} \mathrm{GC}$ analyses were performed on a Perkin-Elmer Clarus 500 GC (30 m, Econo-Cap EC-5) with a FID detector. Elemental microanalyses were carried out by the Mikroanalytisches Laboratorium KOLBE, Mülheim an der Ruhr, Germany. $\mathrm{Fe}(\mathrm{OTf})_{2} \cdot 2 \mathrm{MeCN},{ }^{40} \quad(S)$-2-(methoxycarbonyl)pyrrolidinium chloride, ${ }^{41}(S)$-methyl-1-(pyridin-2-ylmethyl)pyrrolidine-2-carboxylate (PyProMe) (1), ${ }^{23}$ 1-(pyridin-2-ylmethyl)pyrrolidine-2carboxamide (PyProNH ${ }_{2}$ ) (5), ${ }^{23}$ diphenyl(1-(pyridin-2-ylmethyl)pyrrolidin-2-yl)methanol $\left(\mathbf{P y P r o P h} \mathbf{P}_{2} \mathbf{O H}\right)(7)^{23}$ were prepared according to published procedures.

$(\boldsymbol{S})$-2-(n-Propoxycarbonyl)pyrrolidinium chloride. $\mathrm{SOCl}_{2}$ (2.6 mL, $36 \mathrm{mmol}$ ) was added dropwise for $15 \mathrm{~min}$ with stirring to anhydrous $n$-propanol $(12 \mathrm{~mL})$ at $0{ }^{\circ} \mathrm{C}$. $S$-Proline $(3.24 \mathrm{~g}, 28.1 \mathrm{mmol})$ was added to this solution at $0{ }^{\circ} \mathrm{C}$. The white suspension was stirred and heated to $60^{\circ} \mathrm{C}$. After $24 \mathrm{~h}$ the light brown solution was evaporated and dried in vacuo $(<0.1 \mathrm{mbar})$ with stirring at $75^{\circ} \mathrm{C}$ for $4 \mathrm{~h}$ to leave a light brown, viscous oil, which was used in the subsequent reaction without further purification $(5.32 \mathrm{~g}, 98 \%)$.

${ }^{1} \mathrm{H}$ NMR (300 MHz, DMSO-d $\left.6,25{ }^{\circ} \mathrm{C}\right): \delta=0.90\left(\mathrm{t}, 3 \mathrm{H},{ }^{3} \mathrm{~J}_{\mathrm{HH}}=\right.$ $7.2 \mathrm{~Hz}, \mathrm{CH}_{3}$ ), 1.64 (sxt, $2 \mathrm{H},{ }^{3} J_{\mathrm{HH}}=7.2 \mathrm{~Hz}, \mathrm{CH}_{2} \mathrm{CH}_{2} \mathrm{CH}_{3}$ ), 1.83-2.03 (m, 3H, $\mathrm{CH}_{2}$ ring, $\gamma$ and $\beta$ to $\left.\mathrm{CO}\right), 2.19-2.33(\mathrm{~m}, 1 \mathrm{H}$, $\mathrm{CH}_{2}$ ring, $\beta$ to $\mathrm{CO}$ ), 3.13-3.28 (m, $2 \mathrm{H}, \mathrm{NCH}_{2}$ ring), 4.06-4.19 $\left(\mathrm{m}, 2 \mathrm{H}, \mathrm{CH}_{2} \mathrm{CH}_{2} \mathrm{CH}_{3}\right.$ ), 4.33-4.38 (m, $1 \mathrm{H}, \mathrm{CH} \alpha$ to $\mathrm{CO}$ ), 9.15 (s, b, 1H, NHH), 10.33 (s, b, 1H, NHH) ppm. ${ }^{13} \mathrm{C}\{1 \mathrm{H}\} \mathrm{NMR}$ (100 $\left.\mathrm{MHz}, \mathrm{CDCl}_{3}, 25{ }^{\circ} \mathrm{C}\right): \delta=10.4,22.0,23.8,29.0,46.1$, 59.4, 68.6, 169.1 ppm. IR (film): $\nu=2965.4,2879.0,1690.4,1739.8$, 1560.4, 1458.4, 1396.4, 1354.3, 1222.8, 1092.6, 1057.4, 998.9, 968.5, 927.9, 903.7, 758.8, $676.1 \mathrm{~cm}^{-1} \cdot[\alpha]_{\mathrm{D}}^{21}-43.3 \mathrm{deg} \mathrm{cm}^{3} \mathrm{~g}^{-1}$ $\mathrm{dm}^{-1}\left(c 0.952, \mathrm{CHCl}_{3}\right)$.

2-(Chloromethyl)pyridinium chloride. A cooled solution of $\mathrm{SOCl}_{2}(2.1 \mathrm{~mL}, 29 \mathrm{mmol})$ in anhydrous $\mathrm{CH}_{2} \mathrm{Cl}_{2}(50 \mathrm{~mL})$ was added dropwise for 30 min with stirring to a colourless solution of pyridin-2-ylmethanol $(2.20 \mathrm{~g}, 20.2 \mathrm{mmol})$ in anhydrous $\mathrm{CH}_{2} \mathrm{Cl}_{2}(50 \mathrm{~mL})$ at $0{ }^{\circ} \mathrm{C}$. After $60 \mathrm{~min}$ stirring at $0{ }^{\circ} \mathrm{C}$, the white turbid solution was allowed to reach ambient temperature. After $60 \mathrm{~min}$, the solution was quenched with $n$-propanol (3.5 $\mathrm{mL})$, stirred for $15 \mathrm{~min}$, evaporated, and dried in vacuo to leave a white powder, which was used in the subsequent reaction without further purification ( $3.31 \mathrm{~g}$, quant.).

${ }^{1} \mathrm{H}$ NMR (400 MHz, DMSO-d $\left.{ }_{6}, 25{ }^{\circ} \mathrm{C}\right): \delta=4.98(\mathrm{~s}, 2 \mathrm{H}$, $\left.\mathrm{ArCH}_{2}\right), 7.75\left(\mathrm{dd}, 1 \mathrm{H},{ }^{3} J_{\mathrm{HH}}=7.6 \mathrm{~Hz},{ }^{3} J_{\mathrm{HH}}=5.6 \mathrm{~Hz}, \operatorname{PyH}(5)\right)$, $7.92\left(\mathrm{~d}, 1 \mathrm{H},{ }^{3} J_{\mathrm{HH}}=8.0 \mathrm{~Hz}, \operatorname{Py} H(3)\right), 8.29\left(\mathrm{t}, 1 \mathrm{H},{ }^{3} J_{\mathrm{HH}}=7.8 \mathrm{~Hz}\right.$, $\mathrm{Py} H(4)), 8.76\left(\mathrm{~d}, 1 \mathrm{H},{ }^{3} J_{\mathrm{HH}}=5.4 \mathrm{~Hz}, \operatorname{Py} H(6)\right) \mathrm{ppm} .{ }^{13} \mathrm{C}\left\{{ }^{1} \mathrm{H}\right\} \mathrm{NMR}$ $\left(100 \mathrm{MHz}, \mathrm{DMSO}_{6}, 25{ }^{\circ} \mathrm{C}\right): \delta=42.9,125.5,125.8,143.2$, 145.2, $153.1 \mathrm{ppm}$.

2-(Chloromethyl)-6-methylpyridinium chloride. $\mathrm{SOCl}_{2}$ $(1.2 \mathrm{~mL}, 17 \mathrm{mmol})$ in anhydrous $\mathrm{CH}_{2} \mathrm{Cl}_{2}(28 \mathrm{~mL})$ was reacted with (6-methylpyridin-2-yl)methanol (1.41 g, $11.4 \mathrm{mmol})$ in anhydrous $\mathrm{CH}_{2} \mathrm{Cl}_{2}(28 \mathrm{~mL})$ in the same manner as described for 2-(chloromethyl)pyridinium chloride. After the solution reached ambient temperature it was stirred for an additional $60 \mathrm{~min}$ at $60{ }^{\circ} \mathrm{C}$ after which the reaction was quenched with ${ }^{n} \mathrm{PrOH}(2.0 \mathrm{~mL})$, stirred for $15 \mathrm{~min}$, evaporated, and dried in vacuo to leave a white powder, which was used in the subsequent reaction without further purification (2.04 g, quant.).

${ }^{1} \mathrm{H}$ NMR (400 MHz, DMSO-d $\left.{ }_{6}, 25{ }^{\circ} \mathrm{C}\right): \delta=2.69(\mathrm{~s}, 3 \mathrm{H}$, $\mathrm{ArCH}_{3}$ ), 5.01 (s, 2H, $\mathrm{ArCH}_{2}$ ), 7.69 (d, $\left.1 \mathrm{H},{ }^{3} \mathrm{~J}_{\mathrm{HH}}=7.6 \mathrm{~Hz}, \mathrm{PyH}(5)\right)$, $7.78\left(\mathrm{~d}, 1 \mathrm{H},{ }^{3} J_{\mathrm{HH}}=8.0 \mathrm{~Hz}, \operatorname{Py} H(3)\right), 8.26\left(\mathrm{t}, 1 \mathrm{H},{ }^{3} J_{\mathrm{HH}}=8.0 \mathrm{~Hz}\right.$, PyH(4)) ppm. ${ }^{13} \mathrm{C}\left\{{ }^{1} \mathrm{H}\right\}$ NMR (100 MHz, DMSO-d $\left.6,25{ }^{\circ} \mathrm{C}\right): \delta=$ 41.9, 62.5, 123.5, 126.2, 143.9, 151.8, 155.5 ppm.

(S)-Methyl-1-((6-methylpyridin-2-yl)methyl)pyrrolidine-2-carboxylate (6-Me-PyProMe) (2). A yellow suspension of 2-(chloromethyl)-6-methylpyridinium chloride (9.62 g, $54.0 \mathrm{mmol})$, (S)-2-(methoxycarbonyl)pyrrolidinium chloride $\quad(12.2 \mathrm{~g}$, $73.5 \mathrm{mmol}$ ), $\mathrm{NaI}(3.08 \mathrm{~g}, 20.5 \mathrm{mmol})$ and $\mathrm{Na}_{2} \mathrm{CO}_{3}(19.0 \mathrm{~g}$, $179 \mathrm{mmol})$ in anhydrous DMF $(140 \mathrm{~mL})$ was stirred at $50{ }^{\circ} \mathrm{C}$. After $16 \mathrm{~h}$ the reaction mixture was taken up in $\mathrm{H}_{2} \mathrm{O}(280 \mathrm{~mL})$ and extracted with $\mathrm{CH}_{2} \mathrm{Cl}_{2}(5 \times 100 \mathrm{~mL})$. The organic phases were combined, washed with $\mathrm{H}_{2} \mathrm{O}(120 \mathrm{~mL})$, dried $\left(\mathrm{Na}_{2} \mathrm{SO}_{4}\right)$, filtered and evaporated. The remaining orange oil was subjected to column chromatography $\left(\mathrm{SiO}_{2}(900 \mathrm{~mL}), \mathrm{Et}_{2} \mathrm{O}-\mathrm{Et}_{3} \mathrm{~N}\right.$ $\left.100: 1 \rightarrow 100: 2(\mathrm{v} / \mathrm{v}), R_{\mathrm{f}}=0.3-0.4\right)$. The remaining impurity $\left({ }^{1} \mathrm{H}\right.$ NMR $\left(\mathrm{CDCl}_{3}\right)$ : 6.82-6.88 (m) and 7.17-7.21 (m)) was removed by heating the oil in vacuo $(<0.5 \mathrm{mbar})$ at $90{ }^{\circ} \mathrm{C}$ for $2 \mathrm{~h}$ to leave a yellow oil $(8.57 \mathrm{~g}, 70 \%)$.

${ }^{1} \mathrm{H}$ NMR (400 $\left.\mathrm{MHz}, \mathrm{CDCl}_{3}, 25{ }^{\circ} \mathrm{C}\right): \delta=1.77-2.01(\mathrm{~m}, 3 \mathrm{H}$, $\mathrm{CH}_{2}$ ring, $\gamma$ and $\beta$ to $\mathrm{CO}$ ), $2.10-2.21$ ( $\mathrm{m}, 1 \mathrm{H}, \mathrm{CH}_{2}$ ring, $\beta$ to $\mathrm{CO}$ ), $2.53\left(\mathrm{~s}, 3 \mathrm{H}, \mathrm{ArCH}_{3}\right), 2.53-2.59$ (m, 1H, NCHH ring), 3.09-3.14 (m, $1 \mathrm{H}, \mathrm{NCH} H$ ring), 3.42-3.46 (m, $1 \mathrm{H}, \mathrm{CH} \alpha$ to $\mathrm{CO}), 3.65(\mathrm{~s}$, $\left.3 \mathrm{H}, \mathrm{CH}_{3}\right), 3.80\left(\mathrm{~d}, 1 \mathrm{H},{ }^{2} \mathrm{~J}_{\mathrm{HH}}=13.6 \mathrm{~Hz}, \mathrm{ArCHHN}\right), 4.01(\mathrm{~d}, 1 \mathrm{H}$, $\left.{ }^{2} J_{\mathrm{HH}}=13.6 \mathrm{~Hz}, \operatorname{ArCH} H \mathrm{~N}\right), 7.01\left(\mathrm{~d}, 1 \mathrm{H},{ }^{3} J_{\mathrm{HH}}=7.6 \mathrm{~Hz}, \operatorname{Py} H(5)\right)$, $7.28\left(\mathrm{~d}, 1 \mathrm{H},{ }^{3} J_{\mathrm{HH}}=7.6 \mathrm{~Hz}, \operatorname{Py} H(3)\right), 7.54\left(\mathrm{t}, 1 \mathrm{H},{ }^{3} J_{\mathrm{HH}}=7.6 \mathrm{~Hz}\right.$, PyH(4)) ppm. ${ }^{13} \mathrm{C}\left\{{ }^{1} \mathrm{H}\right\}$ NMR (100 MHz, $\left.\mathrm{CDCl}_{3}, 25^{\circ} \mathrm{C}\right): \delta=23.4$, 24.5, 29.5, 51.9, 53.7, 60.3, 65.5, 120.5, 121.8, 137.0, 157.6, 158.0, 174.5 ppm. IR (film): $\nu=2951.6,1732.2,1591.4,1577.9$, 1455.8, 1435.4, 1358.2, 1275.0, 1196.0, 1169.4, 1087.1, 1038.4, 995.4, 933.2, 890.9, 783.4, $758.1 \mathrm{~cm}^{-1}$. UV-Vis (MeCN) $\left[\lambda_{\max }\right.$, 
$\left.\mathrm{nm}\left(\varepsilon, \mathrm{M}^{-1} \mathrm{~cm}^{-1}\right)\right]: 207$ (7587), 265 (4096). $[\alpha]_{\mathrm{D}}^{21}-72.1 \mathrm{deg} \mathrm{cm}^{3}$ $\mathrm{g}^{-1} \mathrm{dm}^{-1}$ (c 1.1, $\mathrm{CHCl}_{3}$ ). Anal. for $\mathrm{C}_{13} \mathrm{H}_{18} \mathrm{~N}_{2} \mathrm{O}_{2}$ (234.29): calc. C 66.64, H 7.74, N 11.96; found C 66.54, H 7.83, N 11.90.

n-Propyl-1-(pyridin-2-ylmethyl)pyrrolidine-2-carboxylate (PyProPr) (3). An orange suspension of 2-(chloromethyl)pyridinium chloride (3.30 g, $20.1 \mathrm{mmol}),(S)-2-(n$-propoxycarbonyl)pyrrolidinium chloride (5.32 g, $26.8 \mathrm{mmol})$, NaI (1.19 g, $7.94 \mathrm{mmol})$ and $\mathrm{Na}_{2} \mathrm{CO}_{3}(7.29 \mathrm{~g}, 68.8 \mathrm{mmol})$ in anhydrous DMF $(54 \mathrm{~mL})$ was stirred at $50^{\circ} \mathrm{C}$. After $25 \mathrm{~h}$ the resulting pink suspension was taken up in $\mathrm{H}_{2} \mathrm{O}(110 \mathrm{~mL})$ and extracted with $\mathrm{CH}_{2} \mathrm{Cl}_{2}(5 \times 30 \mathrm{~mL})$. The organic phases were combined, washed with $\mathrm{H}_{2} \mathrm{O}(50 \mathrm{~mL})$, dried $\left(\mathrm{Na}_{2} \mathrm{SO}_{4}\right)$, filtered and evaporated. The remaining red oil was subjected to column chromatography $\left(\mathrm{SiO}_{2}(250 \mathrm{~mL}), \mathrm{Et}_{2} \mathrm{O}\right.$-hexanes-Et ${ }_{3} \mathrm{~N} 75: 25: 2(\mathrm{v} / \mathrm{v})$, $\left.R_{\mathrm{f}}=0.3\right)$. The remaining impurity $\left({ }^{1} \mathrm{H} \mathrm{NMR}\left(\mathrm{CDCl}_{3}\right): 6.83-6.87\right.$ $(\mathrm{m})$ and $7.18-7.22(\mathrm{~m})$ ) was removed by heating the oil in vacuo $(<0.1 \mathrm{mbar})$ at $110^{\circ} \mathrm{C}$ for $1 \mathrm{~h}$ to leave a dark yellow oil $(3.99 \mathrm{~g}$, $80 \%)$.

${ }^{1} \mathrm{H}$ NMR $\left(400 \mathrm{MHz}, \mathrm{CDCl}_{3}, 25{ }^{\circ} \mathrm{C}\right): \delta=0.91\left(\mathrm{t}, 3 \mathrm{H},{ }^{3} \mathrm{~J}_{\mathrm{HH}}=\right.$ $7.2 \mathrm{~Hz}, \mathrm{CH}_{3}$ ), 1.63 (sxt, $2 \mathrm{H},{ }^{3} \mathrm{~J}_{\mathrm{HH}}=7.2 \mathrm{~Hz}, \mathrm{CH}_{2} \mathrm{CH}_{2} \mathrm{CH}_{3}$ ), 1.78-2.03 (m, $3 \mathrm{H}, \mathrm{CH}_{2}$ ring, $\gamma$ and $\beta$ to $\left.\mathrm{CO}\right), 2.12-2.23(\mathrm{~m}, 1 \mathrm{H}$, $\mathrm{CH}_{2}$ ring, $\beta$ to $\mathrm{CO}$ ), 2.53-2.60 (m, $1 \mathrm{H}, \mathrm{NCHH}$ ring), 3.08-3.13 ( $\mathrm{m}, 1 \mathrm{H}, \mathrm{NCH} H$ ring), 3.43-3.46 (m, $1 \mathrm{H}, \mathrm{CH} \alpha$ to $\mathrm{CO}), 3.80$ (d, $\left.1 \mathrm{H},{ }^{2} J_{\mathrm{HH}}=13.6 \mathrm{~Hz}, \operatorname{ArCHHN}\right), 3.99-4.08\left(\mathrm{~m}, 2 \mathrm{H}, \mathrm{CH}_{2} \mathrm{CH}_{2} \mathrm{CH}_{3}\right)$, $4.10\left(\mathrm{~d}, 1 \mathrm{H},{ }^{2} J_{\mathrm{HH}}=13.6 \mathrm{~Hz}, \operatorname{ArCH} H \mathrm{~N}\right), 7.13\left(\mathrm{dd}, 1 \mathrm{H},{ }^{3} J_{\mathrm{HH}}=\right.$ $\left.7.6 \mathrm{~Hz},{ }^{3} J_{\mathrm{HH}}=4.8 \mathrm{~Hz}, \operatorname{PyH}(5)\right), 7.46\left(\mathrm{~d}, 1 \mathrm{H},{ }^{3} J_{\mathrm{HH}}=7.6 \mathrm{~Hz}\right.$, $\operatorname{Py} H(3)), 7.64\left(\mathrm{t}, 1 \mathrm{H},{ }^{3} J_{\mathrm{HH}}=7.6 \mathrm{~Hz}, \operatorname{Py} H(4)\right), 8.50\left(\mathrm{~d}, 1 \mathrm{H},{ }^{3} J_{\mathrm{HH}}=\right.$ $4.8 \mathrm{~Hz}, \mathrm{Py} H(6))$ ppm. ${ }^{13} \mathrm{C}\left\{{ }^{1} \mathrm{H}\right\}$ NMR (100 MHz, $\left.\mathrm{CDCl}_{3}, 25{ }^{\circ} \mathrm{C}\right)$ : $\delta=10.5,22.1,23.3,29.4,53.5,60.2$, 65.5, 66.3, 122.2, 123.5, 136.6, 149.0, 158.9, 174.1 ppm. IR (film): $\nu=2967.0,1728.2$, 1588.8, 1569.9, 1473.9, 1433.3, 1360.5, 1269.9, 1174.1, 1086.8, 1059.3, 1046.3, 993.5, 934.6, 897.1, $757.7 \mathrm{~cm}^{-1}$. UV-Vis (MeCN) $\left[\lambda_{\max }, \mathrm{nm}\left(\varepsilon, \mathrm{M}^{-1} \mathrm{~cm}^{-1}\right)\right]: 202(7617), 261(3024) .[\alpha]_{\mathrm{D}}^{21}-65.4$ deg $\mathrm{cm}^{3} \mathrm{~g}^{-1} \mathrm{dm}^{-1}$ (c $0.8, \mathrm{CHCl}_{3}$ ). Anal. for $\mathrm{C}_{14} \mathrm{H}_{20} \mathrm{~N}_{2} \mathrm{O}_{2}$ (248.32): calc. C 67.71, H 8.12, N 11.28; found C 67.64, H 8.17, N 11.25.

n-Propyl-1-((6-methylpyridin-2-yl)methyl)pyrrolidine-2-carboxylate (6-Me-PyProPr) (4). A yellow suspension of 2-(chloromethyl)-6-methylpyridinium chloride (2.02 g, $11.3 \mathrm{mmol})$, $(S)$-2-(n-propoxycarbonyl)pyrrolidinium chloride $(2.99 \mathrm{~g}$, $15.4 \mathrm{mmol}$ ), $\mathrm{NaI}(0.68 \mathrm{~g}, 4.5 \mathrm{mmol})$ and $\mathrm{Na}_{2} \mathrm{CO}_{3}(4.13 \mathrm{~g}$, $39.0 \mathrm{mmol})$ in anhydrous DMF $(31 \mathrm{~mL})$ was stirred at $50{ }^{\circ} \mathrm{C}$. After $25 \mathrm{~h}$ the faintly yellow suspension was taken up in $\mathrm{H}_{2} \mathrm{O}$ $(60 \mathrm{~mL})$ and extracted with $\mathrm{CH}_{2} \mathrm{Cl}_{2}(5 \times 25 \mathrm{~mL})$. The organic phases were combined, washed with $\mathrm{H}_{2} \mathrm{O}(20 \mathrm{~mL})$, dried $\left(\mathrm{Na}_{2} \mathrm{SO}_{4}\right)$, filtered and evaporated. The remaining orange oil was subjected to column chromatography $\left(\mathrm{SiO}_{2}(200 \mathrm{~mL})\right.$, $\mathrm{Et}_{2} \mathrm{O}$-hexanes- $\mathrm{Et}_{3} \mathrm{~N}$ 75:25:2(v/v), $\left.R_{\mathrm{f}}=0.4\right)$. The remaining impurity was removed by heating the oil in vacuo $(<0.1 \mathrm{mbar})$ at $110{ }^{\circ} \mathrm{C}$ for $60 \mathrm{~min}$ to leave a yellow oil $(2.65 \mathrm{~g}, 89 \%)$.

${ }^{1} \mathrm{H}$ NMR $\left(400 \mathrm{MHz}, \mathrm{CDCl}_{3}, 25{ }^{\circ} \mathrm{C}\right): \delta=0.91\left(\mathrm{t}, 3 \mathrm{H},{ }^{3} J_{\mathrm{HH}}=\right.$ $7.2 \mathrm{~Hz}, \mathrm{CH}_{2} \mathrm{CH}_{2} \mathrm{CH}_{3}$ ), 1.62 (sxt, $2 \mathrm{H},{ }^{3} J_{\mathrm{HH}}=7.2 \mathrm{~Hz}$, $\mathrm{CH}_{2} \mathrm{CH}_{2} \mathrm{CH}_{3}$ ), 1.75-2.01 ( $\mathrm{m}, 3 \mathrm{H}, \mathrm{CH}_{2}$ ring, $\gamma$ and $\beta$ to $\mathrm{CO}$ ), 2.10-2.20 (m, $1 \mathrm{H}, \mathrm{CH}_{2}$ ring, $\beta$ to $\left.\mathrm{CO}\right), 2.51-2.57(\mathrm{~m}, 1 \mathrm{H}, \mathrm{NCHH}$ ring), $2.52\left(\mathrm{~s}, 3 \mathrm{H}, \mathrm{ArCH}_{3}\right), 3.07-3.12(\mathrm{~m}, 1 \mathrm{H}, \mathrm{NCH} H$ ring), 3.39-3.43 (m, 1H, CH $\alpha$ to CO), $3.76\left(\mathrm{~d}, 1 \mathrm{H},{ }^{2} J_{\mathrm{HH}}=14.0 \mathrm{~Hz}\right.$,
ArCHHN), 3.97-4.07 (m, 2H, $\left.\mathrm{CH}_{2} \mathrm{CH}_{2} \mathrm{CH}_{3}\right), 4.04\left(\mathrm{~d}, 1 \mathrm{H},{ }^{2} J_{\mathrm{HH}}=\right.$ $14.0 \mathrm{~Hz}, \operatorname{ArCH} H \mathrm{~N}), 7.00$ (d, 1H, $\left.{ }^{3} J_{\mathrm{HH}}=7.6 \mathrm{~Hz}, \mathrm{Py} H(5)\right), 7.29$ (d, $\left.1 \mathrm{H},{ }^{3} J_{\mathrm{HH}}=7.6 \mathrm{~Hz}, \operatorname{Py} H(3)\right), 7.52\left(\mathrm{t}, 1 \mathrm{H},{ }^{3} J_{\mathrm{HH}}=7.6 \mathrm{~Hz}, \operatorname{Py} H(4)\right)$ ppm. ${ }^{13} \mathrm{C}\left\{{ }^{1} \mathrm{H}\right\}$ NMR $\left(100 \mathrm{MHz}, \mathrm{CDCl}_{3}, 25^{\circ} \mathrm{C}\right): \delta=10.5,22.1$, $23.4,24.5,29.5,53.6,60.3,65.5,66.2,120.3,121.7,136.9$, 157.5, 158.3, $174.2 \mathrm{ppm}$. IR (film): $\nu=2967.7,1728.6,1591.5$, 1578.1, 1456.4, 1357.7, 1267.0, 1173.4, 1086.8, 1059.2, 1040.2, 991.7, 935.4, 900.8, 782.9, $757.5 \mathrm{~cm}^{-1}$. UV-Vis (MeCN) $\left[\lambda_{\max }\right.$, $\left.\mathrm{nm}\left(\varepsilon, \mathrm{M}^{-1} \mathrm{~cm}^{-1}\right)\right]: 207$ (8018), 265 (4347). $[\alpha]_{\mathrm{D}}^{21}-65.8 \mathrm{deg} \mathrm{cm}^{3}$ $\mathrm{g}^{-1} \mathrm{dm}^{-1}$ (c 0.7, $\mathrm{CHCl}_{3}$ ). Anal. for $\mathrm{C}_{15} \mathrm{H}_{22} \mathrm{~N}_{2} \mathrm{O}_{2}$ (262.35): calc. C 68.67, H 8.45, N 10.68; found C 68.57, H 8.65, N 10.63.

1-((6-Methylpyridin-2-yl)methyl)pyrrolidine-2-carboxamide (6-Me-PyProNH $\mathrm{N}_{2}$ ) (6). A colorless solution of 2 (3.48 g, $14.9 \mathrm{mmol})$ in anhydrous $\mathrm{MeOH}(60 \mathrm{~mL})$ was saturated with $\mathrm{NH}_{3}$ at $0{ }^{\circ} \mathrm{C}$ for $30 \mathrm{~min}$. The solution was allowed to reach ambient temperature and after 6 days was evaporated to dryness. The remaining yellow oil was dissolved in a small amount of eluent and subjected to column chromatography $\left(\mathrm{SiO}_{2}(400 \mathrm{~mL}), \mathrm{Et}_{2} \mathrm{O}-\mathrm{MeOH}-\mathrm{Et}_{3} \mathrm{~N} 30: 1: 1 \rightarrow 30: 3: 1(\mathrm{v} / \mathrm{v}), R_{\mathrm{f}}=\right.$ 0.3-0.4). The remaining impurity $\left({ }^{1} \mathrm{H}\right.$ NMR $\left(\mathrm{CDCl}_{3}\right): 6.83-6.86$ (m) and 7.17-7.21 (m)) was removed by heating in vacuo $(<0.5 \mathrm{mbar})$ at $100{ }^{\circ} \mathrm{C}$ for $2 \mathrm{~h}$ to leave a yellow, highly viscous oil, which solidified upon standing for several weeks $(2.65 \mathrm{~g}$, $81 \%)$.

${ }^{1} \mathrm{H}$ NMR (400 MHz, $\left.\mathrm{CDCl}_{3}, 25{ }^{\circ} \mathrm{C}\right): \delta=1.72-1.85(\mathrm{~m}, 2 \mathrm{H}$, $\mathrm{CH}_{2}$ ring, $\gamma$ to $\mathrm{CO}$ ), 1.94-2.02 ( $\mathrm{m}, 1 \mathrm{H}, \mathrm{CH}_{2}$ ring, $\beta$ to $\mathrm{CO}$ ), 2.21-2.31 (m, $1 \mathrm{H}, \mathrm{CH}_{2}$ ring, $\beta$ to $\left.\mathrm{CO}\right), 2.48-2.55(\mathrm{~m}, 1 \mathrm{H}, \mathrm{NCHH}$ ring), $2.53\left(\mathrm{~s}, 3 \mathrm{H}, \mathrm{ArCH}_{3}\right), 3.07-3.12(\mathrm{~m}, 1 \mathrm{H}, \mathrm{NCH} H$ ring), 3.37 (s (br), $1 \mathrm{H}, \mathrm{CH} \alpha$ to $\mathrm{CO}), 3.72\left(\mathrm{~d}, 1 \mathrm{H},{ }^{2} J_{\mathrm{HH}}=13.6 \mathrm{~Hz}, \operatorname{ArCHHN}\right)$, $3.99\left(\mathrm{~d}, 1 \mathrm{H},{ }^{2} J_{\mathrm{HH}}=13.6 \mathrm{~Hz}, \operatorname{ArCH} H \mathrm{~N}\right), 5.58(\mathrm{~s}(\mathrm{br}), 1 \mathrm{H}, \mathrm{NHH})$, $7.03\left(\mathrm{~d}, 1 \mathrm{H},{ }^{3} J_{\mathrm{HH}}=7.6 \mathrm{~Hz}, \operatorname{Py} H(5)\right), 7.06\left(\mathrm{~d}, 1 \mathrm{H},{ }^{3} J_{\mathrm{HH}}=7.6 \mathrm{~Hz}\right.$ $\mathrm{PyH}(3)), 7.53\left(\mathrm{t}, 1 \mathrm{H},{ }^{3} \mathrm{JHH}_{\mathrm{HH}}=7.6 \mathrm{~Hz}, \mathrm{PyH}(4)\right), 8.01$ (s (br), $1 \mathrm{H}$, $\mathrm{NH} H)$ ppm. ${ }^{13} \mathrm{C}\left\{{ }^{1} \mathrm{H}\right\}$ NMR (100 MHz, $\left.\mathrm{CDCl}_{3}, 25{ }^{\circ} \mathrm{C}\right): \delta=24.4$, 24.6, 30.7, 54.3, 61.1, 67.4, 119.8, 122.1, 137.1, 157.7, 158.4, 177.9 ppm. IR (solid): $\nu=3388.2,3191.1,2972.0,2920.6$, 2872.6, 2825.5, 1624.5, 1594.4, 1576.8, 1460.0, 1402.2, 1374.8, 1331.9, 1310.0, 1275.1, 1235.0, 1196.8, 1156.3, 1111.2, 983.3, 899.8, $785.6 \mathrm{~cm}^{-1}$. UV-Vis (MeCN) $\left[\lambda_{\max }, \mathrm{nm}\left(\varepsilon, \mathrm{M}^{-1} \mathrm{~cm}^{-1}\right)\right]$ : 199 (8820), 265 (4012). $[\alpha]_{\mathrm{D}}^{21}-42.3 \mathrm{deg} \mathrm{cm}^{3} \mathrm{~g}^{-1} \mathrm{dm}^{-1}$ (c 0.6, $\mathrm{CHCl}_{3}$ ). Anal. for $\mathrm{C}_{12} \mathrm{H}_{17} \mathrm{~N}_{3} \mathrm{O}$ (219.28): calc. C 65.73, $\mathrm{H}$ 7.81, N 19.16; found C 65.64, H 7.76, N 19.05.

(1-((6-Methylpyridin-2-yl)methyl)pyrrolidin-2-yl)diphenylmethanol (6-Me-PyProPh ${ }_{2} \mathrm{OH}$ ) (8). Cut and oven-dried $\mathrm{Mg}$ turnings were stirred and heated under $\mathrm{N}_{2}$. After $30 \mathrm{~min}$ they were wetted with anhydrous THF and treated with 8 drops of 1,2-dibromoethane. The mixture was heated for $5 \mathrm{~min}$, stirred for $30 \mathrm{~min}$, diluted with THF $(15 \mathrm{~mL})$, and subsequently treated dropwise for $40 \mathrm{~min}$ with a solution of anhydrous bromobenzene in THF $(30 \mathrm{~mL})$ with stirring. After stirring for $20 \mathrm{~h}$ the mixture was concentrated in vacuo (to $24 \mathrm{~mL}$ ). The grey suspension was cooled to $0{ }^{\circ} \mathrm{C}$ and subsequently treated dropwise for $60 \mathrm{~s}$ via a cannula with a solution of $2(2.14 \mathrm{~g}$, $9.14 \mathrm{mmol})$ in THF $(10 \mathrm{~mL})$ with vigorous stirring. The green solution was allowed to reach ambient temperature. After $60 \mathrm{~min}$ of stirring the solution was acidified with $2 \mathrm{M} \mathrm{HCl}$ (40 mL), and after $30 \mathrm{~min}$ the aqueous phase was basified to 
pH 8 with $2 \mathrm{M} \mathrm{NaOH}$. After separation of the organic phase, the aqueous phase was extracted with $\mathrm{CH}_{2} \mathrm{Cl}_{2}(2 \times 80 \mathrm{~mL}, 1 \times$ $40 \mathrm{~mL}$ ). The combined organic phases were washed with $\mathrm{H}_{2} \mathrm{O}$ $(60 \mathrm{~mL})$, dried $\left(\mathrm{Na}_{2} \mathrm{SO}_{4}\right)$, filtered, and evaporated. The remaining yellow solid was dissolved in $\mathrm{CH}_{2} \mathrm{Cl}_{2}(10 \mathrm{~mL})$, purified by column chromatography $\left(\mathrm{SiO}_{2}(250 \mathrm{~mL})\right.$, hexanes-EtOAc $4: 1$ $\rightarrow 0: 1(\mathrm{v} / \mathrm{v}), R_{\mathrm{f}}$ (hexanes-EtOAc $\left.\left.2: 1\right)=0.4\right)$, and dried in vacuo to leave a white powder $(2.80 \mathrm{~g}, 85 \%)$.

${ }^{1} \mathrm{H}$ NMR (400 MHz, $\mathrm{CDCl}_{3}, 25{ }^{\circ} \mathrm{C}$ ): $\delta=1.66$ (s (br), $2 \mathrm{H}, \mathrm{CH}_{2}$ ring, $\gamma$ to $\mathrm{CO}$ ), 1.79 (s (br), $1 \mathrm{H}, \mathrm{CH}_{2}$ ring, $\beta$ to $\mathrm{CO}$ ), 1.92-2.02 ( $\mathrm{m}, 1 \mathrm{H}, \mathrm{CH}_{2}$ ring, $\beta$ to $\mathrm{CO} H$ ), 2.44-2.65 (m, $1 \mathrm{H}, \mathrm{NCHH}$ ring), 2.49 (s, 3H, $\mathrm{ArCH}_{3}$ ), 3.03 (s (br), 1H, NCHH ring), 3.40 (s (br), $2 \mathrm{H}, \mathrm{CH} \alpha$ to $\mathrm{CO}$ and $\mathrm{ArCHHN}), 4.12$ (s (br), $1 \mathrm{H}, \operatorname{ArCH} H \mathrm{~N}), 5.16$ (s (br), 1H, OH), 6.93 (d, 1H, $\left.{ }^{3} J_{\mathrm{HH}}=7.6 \mathrm{~Hz} \mathrm{PyH}(5)\right), 6.97(\mathrm{~d}, 1 \mathrm{H}$, $\left.{ }^{3} J_{\mathrm{HH}}=7.6 \mathrm{~Hz}, \mathrm{Py} H(3)\right), 7.08\left(\mathrm{t}, 1 \mathrm{H},{ }^{3} J_{\mathrm{HH}}=7.2 \mathrm{~Hz}, p-\mathrm{PhH}\right), 7.16$ $\left(\mathrm{t}, 1 \mathrm{H},{ }^{3} J_{\mathrm{HH}}=7.6 \mathrm{~Hz}, p-\mathrm{Ph} H\right), 7.22\left(\mathrm{t}, 2 \mathrm{H},{ }^{3} J_{\mathrm{HH}}=7.6 \mathrm{~Hz}\right.$, $m-\mathrm{Ph} H), 7.29\left(\mathrm{t}, 2 \mathrm{H},{ }^{3} J_{\mathrm{HH}}=7.6 \mathrm{~Hz}, m-\mathrm{Ph} H\right), 7.48\left(\mathrm{t}, 1 \mathrm{H},{ }^{3} J_{\mathrm{HH}}=\right.$ $7.6 \mathrm{~Hz}, \mathrm{Py} H(4)), 7.58\left(\mathrm{~d}, 2 \mathrm{H},{ }^{3} J_{\mathrm{HH}}=7.6 \mathrm{~Hz}, o-\mathrm{Ph} H\right), 7.68(\mathrm{~d}, 2 \mathrm{H}$, $\left.{ }^{3} J_{\mathrm{HH}}=7.6 \mathrm{~Hz}, o-\mathrm{Ph} H\right) \mathrm{ppm} .{ }^{13} \mathrm{C}\left\{{ }^{1} \mathrm{H}\right\} \mathrm{NMR}\left(100 \mathrm{MHz}, \mathrm{CDCl}_{3}\right.$, $\left.25^{\circ} \mathrm{C}\right): \delta=24.5,29.8,55.9,62.3,71.3,78.2,119.5,121.5,125.9$, 126.4, 126.6, 128.2, 128.3, 136.8, 146.5, 157.4 ppm. IR (solid): $\nu=3267.6,2966.6,2947.0,2821.8,1592.1,1577.5,1487.2$, 1449.1, 1393.0, 1300.0, 1250.0, 1206.3, 1155.8, 1135.0, 1106.4, 1083.3, 1062.1, 1032.5, 962.3, 944.3, 924.9, 895.6, 870.1, 832.1, 795.0, 767.4, 753.3, 711.1, 703.3, $658.7 \mathrm{~cm}^{-1}$. UV-Vis (MeCN) $\left[\lambda_{\max }, \mathrm{nm}\left(\varepsilon, \mathrm{M}^{-1} \mathrm{~cm}^{-1}\right)\right]: 203(55625), 265(7885) \cdot[\alpha]_{\mathrm{D}}^{21}+54.3$ deg $\mathrm{cm}^{3} \mathrm{~g}^{-1} \mathrm{dm}^{-1}$ (c 0.6, $\left.\mathrm{CHCl}_{3}\right)$. Anal. for $\mathrm{C}_{24} \mathrm{H}_{26} \mathrm{~N}_{2} \mathrm{O}$ (358.48): calc. C 80.41, H 7.31, N 7.81; found C 80.46, H 7.37, N 7.78.

$\left[\mathrm{Fe}(\text { PyProPr })_{2}\right](\mathrm{OTf})_{2}$ (9). A solution of $\mathrm{Fe}(\mathrm{OTf})_{2} \cdot 2 \mathrm{MeCN}$ (725 mg, $1.66 \mathrm{mmol}$ ) in anhydrous, degassed MeCN (23 mL) was added via a cannula with stirring to a solution of 3 ( $0.83 \mathrm{~g}$, $3.3 \mathrm{mmol}$ ) in $\mathrm{MeCN}$ (23 mL). Immediately upon addition a colour change to yellow was observed. After $60 \mathrm{~min}$ stirring at RT the solvent was evaporated in vacuo to leave an orange foam. The product was purified twice by the addition of $\mathrm{Et}_{2} \mathrm{O}$ $(2 \times 30 \mathrm{~mL})$ to a solution of the product in $\mathrm{MeCN}(2 \times 7 \mathrm{~mL})$ with stirring (for $16 \mathrm{~h}$, for $1 \mathrm{~h}$ ). The colourless supernatants were removed via a cannula. The remaining red-brown oil was dried in vacuo to leave an orange foam. Stirring in vacuo resulted in a white powder with an orange-pink hue $(1.11 \mathrm{~g}$, $78 \%)$.

IR (solid): $\nu=2973.1,1658.7,1608.8,1447.4,1415.6,1365.6$, 1254.8, 1222.9, 1148.4, 1104.7, 1081.9, 1052.9, 1028.0, 930.0, 845.9, $767.9 \mathrm{~cm}^{-1}$. IR (MeCN): $\nu=2250(\nu \mathrm{CN}), 1664(\nu \mathrm{CO})$, $1274\left(\nu_{\mathrm{as}} \mathrm{SO}_{3}\right), 1224\left(\nu_{\mathrm{s}} \mathrm{CF}_{3}\right), 1158\left(\nu_{\mathrm{as}} \mathrm{CF}_{3}\right), 1034\left(\nu_{\mathrm{s}} \mathrm{SO}_{3}\right) \mathrm{cm}^{-1}$. UV-Vis (MeCN) [ $\left.\lambda_{\max }, \mathrm{nm}\left(\varepsilon, \mathrm{M}^{-1} \mathrm{~cm}^{-1}\right)\right]: 205$ (13 387), 260 (6357), 354 (593). $[\alpha]_{\mathrm{D}}^{21} 0 \mathrm{deg} \mathrm{cm}^{3} \mathrm{~g}^{-1} \mathrm{dm}^{-1}$ (c 0.6, MeCN). Anal. for $\mathrm{C}_{30} \mathrm{H}_{40} \mathrm{~F}_{6} \mathrm{FeN}_{4} \mathrm{O}_{10} \mathrm{~S}_{2}$ (850.62): calc. C 42.36, $\mathrm{H}$ 4.74, N 6.59; found $\mathrm{C}$ 42.18, $\mathrm{H}$ 4.75, N 6.62. ESI-MS: $m / z=701.191$ ([M OTf $]^{+}$, calc. 701.192). Solution magnetic moment (Evans' method): $\mu_{\text {eff }}=4.86 \mu_{\mathrm{B}}$.

$\left[\mathrm{Fe}\left(\text { PyProNH }_{2}\right)_{2}\right](\mathrm{OTf})_{2}$ (10). A solution of $\mathrm{Fe}(\mathrm{OTf})_{2} \cdot 2 \mathrm{MeCN}$ (476 mg, $1.09 \mathrm{mmol}$ ) in anhydrous, degassed MeCN (15 mL) was added via a cannula with stirring to a solution of $5(0.46 \mathrm{~g}$, $2.2 \mathrm{mmol}$ ) in MeCN (15 mL). Immediately upon addition a colour change to yellow was observed. After $60 \mathrm{~min}$ stirring at
RT the solvent was evaporated in vacuo to leave a bright yellow foam. The product was precipitated by the addition of $\mathrm{Et}_{2} \mathrm{O}$ $(40 \mathrm{~mL})$ to a solution of the product in MeCN $(5 \mathrm{~mL})$ with stirring for $60 \mathrm{~min}$. The colourless supernatant was removed via a cannula. The remaining yellow powder was recrystallized from MeCN $(5 \mathrm{~mL})$ by the addition of $\mathrm{Et}_{2} \mathrm{O}(25 \mathrm{~mL})$ and dried in vacuo (752 mg, 90\%). Slow vapour diffusion of $\mathrm{Et}_{2} \mathrm{O}$ into a concentrated solution of 10 in MeCN yielded yellow, needleshaped crystals suitable for X-ray diffraction.

IR (solid): $\nu=3353.1,1673.6,1592.4,1481.8,1439.7,1249.9$, 1224.5, 1149.2, 1106.5, 1055.0, 1026.8, 991.7, 926.6, 843.5, 781.6, $757.2 \mathrm{~cm}^{-1}$. IR (MeCN): $\nu=2250(\nu \mathrm{CN}), 1668(\nu \mathrm{CO})$, $1270\left(\nu_{\mathrm{as}} \mathrm{SO}_{3}\right), 1227\left(\nu_{\mathrm{s}} \mathrm{CF}_{3}\right), 1158\left(\nu_{\mathrm{as}} \mathrm{CF}_{3}\right), 1031\left(\nu_{\mathrm{s}} \mathrm{SO}_{3}\right) \mathrm{cm}^{-1}$. UV-Vis (MeCN) $\left[\lambda_{\max }, \mathrm{nm}\left(\varepsilon, \mathrm{M}^{-1} \mathrm{~cm}^{-1}\right)\right]: 365$ (785). $[\alpha]_{\mathrm{D}}^{21}+208$ deg $\mathrm{cm}^{3} \mathrm{~g}^{-1} \mathrm{dm}^{-1}$ (c $0.3, \mathrm{MeCN}$ ). Anal. for $\mathrm{C}_{24} \mathrm{H}_{30} \mathrm{~F}_{6} \mathrm{FeN}_{6} \mathrm{O}_{8} \mathrm{~S}_{2}$ (764.50): calc. C 37.71, H 3.96, N 10.99; found C 37.85, H 4.06, $\mathrm{N}$ 11.05. ESI-MS: $m / z=615.125$ ([M - OTf $]^{+}$, calc. 615.130). Solution magnetic moment (Evans' method): $\mu_{\text {eff }}=4.46 \mu_{\mathrm{B}}$.

$\left[\mathrm{Fe}\left(\mathrm{PyProPh}_{2} \mathrm{OH}\right)_{2}\right](\mathrm{OTf})_{2}$ (11). A solution of $\mathrm{Fe}(\mathrm{OTf})_{2}$. $2 \mathrm{MeCN}$ (636 mg, $1.46 \mathrm{mmol}$ ) in anhydrous, degassed MeCN $(20 \mathrm{~mL})$ was added via a cannula with stirring to a solution of $7(1.01 \mathrm{~g}, 2.93 \mathrm{mmol})$ in $\mathrm{CH}_{2} \mathrm{Cl}_{2}(22 \mathrm{~mL})$. Immediately upon addition a colour change to bright yellow was observed. After 60 min stirring at RT the solvent was evaporated in vacuo to leave a yellow solid. The product was recrystallized twice by the addition of $\mathrm{Et}_{2} \mathrm{O}(50 \mathrm{~mL}, 65 \mathrm{~mL})$ to a solution of the product in MeCN (10 mL, $12 \mathrm{~mL}$ ). The yellow supernatants were removed via a cannula. The remaining off-white powder was dried in vacuo (939 mg, 62\%). IR (solid): $\nu=3338.5$ (b), 2972.4, 1610.1, 1574.4, 1491.5, 1449.3, 1430.2, 1277.0, 1243.6, 1222.6, 1156.8, 1110.6, 1074.9, 1055.2, 1027.0, 936.1, 889.4, 844.3, 768.9, $747.8,707.3,696.3,663.9 \mathrm{~cm}^{-1}$. UV-Vis (MeCN) $\left[\lambda_{\max }, \mathrm{nm}(\varepsilon\right.$, $\left.\mathrm{M}^{-1} \mathrm{~cm}^{-1}\right)$ ]: 204 (65 048), 259 (12 570), 331 (3900). $[\alpha]_{\mathrm{D}}^{21}-21 \mathrm{deg}$ $\mathrm{cm}^{3} \mathrm{~g}^{-1} \mathrm{dm}^{-1}$ (c 0.5, MeCN). Anal. for $\mathrm{C}_{48} \mathrm{H}_{48} \mathrm{~F}_{6} \mathrm{FeN}_{4} \mathrm{O}_{8} \mathrm{~S}_{2}$ (1042.88): calc. C 55.28, H 4.64, N 5.37; found C 55.20, H 4.99, N 5.46. ESI-MS: $m / z=893.269$ ([M - OTf $]^{+}$, calc. 893.265). Solution magnetic moment (Evans' method): $\mu_{\text {eff }}=4.58 \mu_{\mathrm{B}}$.

[Fe(PyProMe)Cl $\mathrm{Cl}_{2}$ (12). A solution of $\mathrm{FeCl}_{2}$ (81 $\mathrm{mg}$, $0.64 \mathrm{mmol})$ in anhydrous, degassed $\mathrm{MeOH}(4 \mathrm{~mL})$ was added via a cannula with stirring to a solution of 1 (140 mg, $0.64 \mathrm{mmol})$ in $\mathrm{MeOH}(4 \mathrm{~mL})$. Immediately upon addition a colour change to yellow was observed. After $60 \mathrm{~min}$ stirring at RT the solvent was evaporated in vacuo to leave a yellow solid/ oil. The product was precipitated by the addition of $\mathrm{Et}_{2} \mathrm{O}$ to a solution of the product in $\mathrm{MeOH}$. The colorless supernatant was removed via a cannula. The remaining yellow powder was dried in a stream of $\mathrm{N}_{2}$ and subsequently in vacuo $(206 \mathrm{mg}$, $93 \%$ ). Slow vapour diffusion of $\mathrm{Et}_{2} \mathrm{O}$ into a concentrated solution of 12 in $\mathrm{MeOH}$ yielded yellow crystalline needles suitable for X-ray diffraction. Slow solvent diffusion of $\mathrm{Et}_{2} \mathrm{O}$ into a concentrated solution of 12 in $\mathrm{CH}_{2} \mathrm{Cl}_{2}$ at RT yielded yellow, blocky crystals suitable for X-ray diffraction.

IR (solid): $\nu=3285.4$ (b), 2966.7, 2907.4, 1696.6, 1602.3, 1568.7, 1476.8, 1442.0, 1388.4, 1366.0, 1346.2, 1296.9, 1271.8, 1254.5, 1171.2, 1099.4, 1077.4, 1050.4, 1025.8, 996.4, 958.6, 931.9, 912.1, 872.8, 859.0, 825.6, 783.1, 771.3, $665.2 \mathrm{~cm}^{-1}$. IR 
(MeCN): $\nu=2247(\nu \mathrm{CN}), 1668(\nu \mathrm{CO}) \mathrm{cm}^{-1}$. UV-Vis $(\mathrm{MeCN})$ $\left[\lambda_{\max }, \mathrm{nm}\left(\varepsilon, \mathrm{M}^{-1} \mathrm{~cm}^{-1}\right)\right]: 291$ (866), $363(501) \cdot[\alpha]_{\mathrm{D}}^{21}+24.9 \mathrm{deg}$ $\mathrm{cm}^{3} \mathrm{~g}^{-1} \mathrm{dm}^{-1}$ (c $0.42, \mathrm{MeCN}$ ). Anal. for $\mathrm{C}_{13} \mathrm{H}_{20} \mathrm{Cl}_{2} \mathrm{FeN}_{2} \mathrm{O}_{3}$ (379.06): calc. C 41.19, H 5.32, N 7.39; found C 41.11, H 5.71, N 7.26. ESI-MS: $m / z=311.025\left([\mathrm{M}-\mathrm{Cl}]^{+}\right.$, calc. 311.025$)$. Solution magnetic moment (Evans' method): $\mu_{\text {eff }}=4.62 \mu_{\mathrm{B}}$.

[Fe(6-Me-PyProMe)Cl $\mathbf{C l}_{2}$ (13). Reacting $\mathrm{FeCl}_{2} \quad(100 \mathrm{mg}$, $0.79 \mathrm{mmol}$ ) with $2(185 \mathrm{mg}, 0.79 \mathrm{mmol})$ in the manner described for 12 yielded 13 as a yellow powder (258 mg, 90\%). Slow vapour diffusion of $\mathrm{Et}_{2} \mathrm{O}$ into a concentrated solution of 13 in $\mathrm{MeOH}$ yielded yellow, blocky crystals suitable for X-ray diffraction.

IR (solid): $\nu=2982.4,2925.3,1687.4,1604.5,1571.2,1442.6$, 1391.1, 1313.1, 1266.0, 1223.0, 1182.3, 1162.0, 1082.4, 1049.8, 1033.1, 1012.0, 984.0, 941.0, 921.5, 872.8, 839.9, 818.2, 786.5, $733.3 \mathrm{~cm}^{-1}$. IR $(\mathrm{MeCN}): \nu=2250(\nu \mathrm{CN}), 1702(\nu \mathrm{CO}) \mathrm{cm}^{-1}$. UV-Vis (MeCN) [ $\left.\lambda_{\max }, \mathrm{nm}\left(\varepsilon, \mathrm{M}^{-1} \mathrm{~cm}^{-1}\right)\right]: 207$ (9910), 267 (4282), 369 (338). $[\alpha]_{\mathrm{D}}^{21}+29.6 \mathrm{deg} \mathrm{cm}^{3} \mathrm{~g}^{-1} \mathrm{dm}^{-1}$ (c 0.448, MeCN). Anal. for $\mathrm{C}_{13} \mathrm{H}_{18} \mathrm{Cl}_{2} \mathrm{FeN}_{2} \mathrm{O}_{2}$ (361.05): calc. C 43.25, $\mathrm{H}$ 5.03, N 7.76; found $\mathrm{C} 43.18, \mathrm{H} 5.14, \mathrm{~N}$ 7.83. ESI-MS: $\mathrm{m} / \mathrm{z}=$ $325.041\left([\mathrm{M}-\mathrm{Cl}]^{+}\right.$, calc. 325.041$)$. Solution magnetic moment (Evans' method): $\mu_{\text {eff }}=5.07 \mu_{\mathrm{B}}$.

[Fe(PyProNH $\left.\left.{ }_{2}\right) \mathbf{C l}_{2}\right]$ (14). Reacting $\mathrm{FeCl}_{2}(104 \mathrm{mg}, 0.82 \mathrm{mmol})$ with 5 (168 $\mathrm{mg}, 0.82 \mathrm{mmol}$ ) in the manner described for 12 yielded 14 as a yellow powder (245 mg, 90\%). Slow vapour diffusion of $\mathrm{Et}_{2} \mathrm{O}$ into a concentrated solution of $\mathbf{1 4}$ in MeCN yielded yellow, blocky crystals suitable for X-ray diffraction.

IR (solid): $\nu=3315.1,3162.0,2972.0,1652.3,1602.1,1476.1$, 1444.5, 1383.9, 1299.6, 1155.1, 1102.8, 1052.1, 1019.1, 963.2, 927.8, $766.5 \mathrm{~cm}^{-1}$. IR $(\mathrm{MeCN}): \nu=2247(\nu \mathrm{CN}), 1668(\nu \mathrm{CO})$ $\mathrm{cm}^{-1}$. UV-Vis (MeCN) $\left[\lambda_{\max }, \mathrm{nm}\left(\varepsilon, \mathrm{M}^{-1} \mathrm{~cm}^{-1}\right)\right]: 385$ (469). $[\alpha]_{\mathrm{D}}^{21}+60 \mathrm{deg} \mathrm{cm}^{3} \mathrm{~g}^{-1} \mathrm{dm}^{-1}$ (c $\left.0.3, \mathrm{MeOH}\right)$. ESI-MS: $\mathrm{m} / z=$ $296.026\left([\mathrm{M}-\mathrm{Cl}]^{+}\right.$, calc. 296.025). Solution magnetic moment (Evans' method): $\mu_{\text {eff }}=4.33 \mu_{\mathrm{B}}$.

[Fe(6-Me-PyProNH $\left.\left.{ }_{2}\right) \mathrm{Cl}_{2}\right]$ (15). Reacting $\mathrm{FeCl}_{2} \quad(102 \mathrm{mg}$, $0.80 \mathrm{mmol})$ with 6 (176 $\mathrm{mg}, 0.80 \mathrm{mmol})$ in the manner described for 12 yielded 15 as a yellow powder (260 mg, 94\%). Slow vapour diffusion of $\mathrm{Et}_{2} \mathrm{O}$ into a concentrated solution of 15 in $\mathrm{MeOH}$ yielded yellow, needle-shaped crystals suitable for $\mathrm{X}$-ray diffraction.

IR (solid): $\nu=3322.0,3250.9,3170.8,2964.0,2900.9,1656.9$, 1604.7, 1591.4, 1467.2, 1455.7, 1384.6, 1357.3, 1304.8, 1218.3, 1168.5, 1123.8, 1101.0, 1015.0, 895.1, 797.6, $781.8 \mathrm{~cm}^{-1}$. UV-Vis $(\mathrm{MeCN})\left[\lambda_{\max }, \mathrm{nm}\left(\varepsilon, \mathrm{M}^{-1} \mathrm{~cm}^{-1}\right)\right]: 385(456) \cdot[\alpha]_{\mathrm{D}}^{21}$ $+71 \mathrm{deg} \mathrm{cm}^{3} \mathrm{~g}^{-1} \mathrm{dm}^{-1}$ (c $\left.0.4, \mathrm{MeOH}\right)$. Anal. for $\mathrm{C}_{12} \mathrm{H}_{17} \mathrm{Cl}_{2} \mathrm{FeN}_{3} \mathrm{O}$ (346.03): calc. C 41.65, $\mathrm{H} 4.95, \mathrm{~N} 12.14$; found C 41.48, H 4.91, N 11.96. ESI-MS: $m / z=310.040\left([\mathrm{M}-\mathrm{Cl}]^{+}\right.$, calc. 310.041). Solution magnetic moment (Evans' method): $\mu_{\text {eff }}=5.10 \mu_{\mathrm{B}}$.

$\left[\mathrm{Fe}\left(\mathbf{P y P r O P h}_{2} \mathbf{O H}\right) \mathrm{Cl}_{2}\right]$ (16). Reacting $\mathrm{FeCl}_{2} \quad(72 \mathrm{mg}$, $0.57 \mathrm{mmol})$ with $7(197 \mathrm{mg}, 0.57 \mathrm{mmol})$ in $\mathrm{CH}_{2} \mathrm{Cl}_{2}(5 \mathrm{~mL})$ in the manner described for $\mathbf{1 2}$ yielded $\mathbf{1 6}$ as a yellow powder (242 mg, 90\%). Slow solvent diffusion of $\mathrm{Et}_{2} \mathrm{O}$ into a concentrated solution of 16 in $\mathrm{CH}_{2} \mathrm{Cl}_{2}$ yielded yellow, blocky crystals suitable for X-ray diffraction.
IR (solid): $\nu=3060.0,2988.8,1605.0,1483.4,1444.4,1369.4$, 1343.9, 1325.3, 1275.4, 1176.8, 1152.4, 1066.2, 1049.7, 1011.8, 960.8, 940.3, 905.4, 855.7, 778.4, 752.1, 696.5, $665.0 \mathrm{~cm}^{-1}$. UV-Vis (MeCN) [ $\left.\lambda_{\max }, \mathrm{nm}\left(\varepsilon, \mathrm{M}^{-1} \mathrm{~cm}^{-1}\right)\right]: 255$ (7096), 292 (5319). $[\alpha]_{\mathrm{D}}^{21}-32 \mathrm{deg} \mathrm{cm}^{3} \mathrm{~g}^{-1} \mathrm{dm}^{-1}$ (c 0.1, MeCN). Anal. for $\mathrm{C}_{23} \mathrm{H}_{24} \mathrm{Cl}_{2} \mathrm{FeN}_{2} \mathrm{O}$ (471.20): calc. C 58.63, H 5.13, N 5.95; found C 58.58, H 5.20, N 5.86. ESI-MS: $m / z=435.091$ ([M $-\mathrm{Cl}]^{+}$, calc. 435.093). Solution magnetic moment (Evans' method): $\mu_{\mathrm{eff}}=$ $5.44 \mu_{\mathrm{B}}$.

[Fe(6-Me-PyProPh $\left.{ }_{2} \mathrm{OH}\right) \mathrm{Cl}_{2}$ ] (17). Reacting $\mathrm{FeCl}_{2}$ (75 mg, $0.59 \mathrm{mmol})$ with $8(212 \mathrm{mg}, 0.59 \mathrm{mmol})$ in $\mathrm{CH}_{2} \mathrm{Cl}_{2}(5 \mathrm{~mL})$ in the manner described for 12 yielded $\mathbf{1 7}$ as a yellow powder (245 mg, 85\%). Slow solvent diffusion of $\mathrm{Et}_{2} \mathrm{O}$ into a concentrated solution of 17 in $\mathrm{CH}_{2} \mathrm{Cl}_{2}$ yielded yellow, blocky crystals suitable for X-ray diffraction.

IR (solid): $\nu=3059.0,2974.3,1606.2,1574.6,1491.4,1463.1$, 1446.7, 1382.0, 1345.3, 1321.9, 1274.4, 1160.9, 1084.7, 1067.3, 1037.2, 1005.9, 907.7, 853.9, 782.9, 747.4, 705.5, 695.0, $657.4 \mathrm{~cm}^{-1}$. UV-Vis (MeCN) $\left[\lambda_{\max }, \mathrm{nm}\left(\varepsilon, \mathrm{M}^{-1} \mathrm{~cm}^{-1}\right)\right]: 205$ (21 889), 261 (7282), 316 (4139). $[\alpha]_{\mathrm{D}}^{21}+19 \mathrm{deg} \mathrm{cm} \mathrm{g}^{-1} \mathrm{dm}^{-1}$ (c $0.1, \mathrm{MeCN}$ ). Anal. for $\mathrm{C}_{24} \mathrm{H}_{26} \mathrm{Cl}_{2} \mathrm{FeN}_{2} \mathrm{O}$ (485.23): calc. C 59.41, H 5.40, N 5.77; found C 59.33, H 5.36, N 5.66. ESI-MS: $m / z=449.106\left([\mathrm{M}-\mathrm{Cl}]^{+}\right.$, calc. 449.108). Solution magnetic moment (Evans' method): $\mu_{\mathrm{eff}}=5.23 \mu_{\mathrm{B}}$.

\section{Protocol for catalytic olefin oxidation}

To a solution of Fe-complex $(3.5 \mu \mathrm{mol})$ in anhydrous, degassed acetonitrile was added substrate $(1.75 \mathrm{mmol})$ to obtain a total volume of $3.0 \mathrm{~mL}$. Subsequently, $0.5 \mathrm{~mL}$ of oxidant solution (700 mM solution in acetonitrile diluted from 35\% aqueous $\mathrm{H}_{2} \mathrm{O}_{2}$ ) was added portionwise for $30 \mathrm{~min}$. The reaction mixture was stirred at room temperature and after $1 \mathrm{~h}$ (from start of oxidant addition) internal standard (10 $\mu \mathrm{L}$, cyclooctene: 1,2dibromobenzene, all other substrates: bromobenzene) was added and the first sample was taken. To an aliquot of the reaction mixture was added diethyl ether. The sample was analysed by GC. The products were identified and quantified by comparison with authentic compounds.

\section{X-ray crystal structure determinations}

Reflections were measured on a Nonius KappaCCD diffractometer with a rotating anode and a graphite monochromator $(\lambda=0.71073 \AA)$. Intensity data were integrated with the software Eval14 $^{42}$ (compound 10), Eval15 ${ }^{43}$ (compound 15) or HKL $2000^{44}$ (compounds 12a, 12b, 13, 14, 16, 17). Absorption correction and scaling was performed based on multiple measured reflections with SADABS ${ }^{45}(\mathbf{1 0 - 1 5})$ or $\operatorname{SORTAV}^{46}(\mathbf{1 6}$, 17). The structures were solved by direct methods using the programs SHELXS-97 ${ }^{47}(\mathbf{1 0}, \mathbf{1 2 b}, \mathbf{1 3 - 1 7})$ or $\mathrm{SIR}^{-97^{48}}$ (12a). Least-squares refinement was performed using SHELXL-97 $7^{47}$ against $F^{2}$ of all reflections. Non-hydrogen atoms were refined freely with anisotropic displacement parameters. Hydrogen atoms were introduced in calculated positions $(\mathbf{1 0}, \mathbf{1 2 a}, \mathbf{1 3})$ or located in difference Fourier maps (12b, 14-17). Hydrogen atoms were refined with a riding model, the $\mathrm{N}-\mathrm{H}$ or $\mathrm{O}-\mathrm{H}$ hydrogen atoms of $\mathbf{1 2 b}, \mathbf{1 4}$, and 15 were refined freely with 
isotropic displacement parameters. The crystal structure of $\mathbf{1 0}$ was refined as a twin with $(-1,0,0 / 0,-1,0 / 1,0,1)$ as twin matrix (pseudo-orthorhombic C-centred lattice). The twin fraction refined to $0.4877(13)$. The triflate anions in $\mathbf{1 0}$ were refined with disorder models using restraints for distances and angles and for the approximation of isotropic behaviour. Geometry calculations and checking for higher symmetry were performed using the PLATON program. ${ }^{49}$ Further details of the crystal structure determinations are given in the ESI Tables S8-S12.†

CCDC 972756-972763 contain the supplementary crystallographic data for this paper.

\section{Acknowledgements}

The work described here was financially supported by the National Research School Combination-Catalysis (NRSC-C).

\section{Notes and references}

1 B. Meunier, Biomimetic Oxidations Catalyzed by Transition Metal Complexes, Imperial College Press, London, 1999.

2 M. Costas, M. P. Mehn, M. P. Jensen and L. Que Jr., Chem. Rev., 2004, 104, 939.

3 (a) A. C. Rosenzweig, C. A. Frederick, S. J. Lippard and P. Nordlund, Nature, 1993, 366, 537; (b) A. C. Rosenzwieg, P. Nordlund, P. M. Takahara, C. A. Frederick and S. J. Lippard, Chem. Biol., 1995, 2, 409; (c) N. Elango, R. Radhakrishnam, W. A. Froland, B. J. Waller, C. A. Earhart, J. D. Lipscomb and D. H. Ohlendorf, Protein Sci., 1997, 6, 556.

4 P. C. A. Bruijnincx, G. van Koten and R. J. M. Klein Gebbink, Chem. Soc. Rev., 2008, 37, 2716.

5 (a) E. G. Kovaleva and J. D. Lipscomb, Nat. Chem. Biol., 2008, 4, 186; (b) K. D. Koehntop, J. P. Emerson and L. Que Jr., J. Biol. Inorg. Chem., 2005, 10, 87.

6 E. L. Hegg, R. Y. K. Ho and L. Que Jr., J. Am. Chem. Soc., 1999, 121, 1972.

7 M. P. Mehn, K. Fujisawa, E. L. Hegg and L. Que Jr., J. Am. Chem. Soc., 2003, 125, 7828.

8 (a) Y. Dong, H. Fujii, M. P. Hendrich, R. A. Leising, G. Pan, C. R. Randall, E. C. Wilkinson, Y. Zang, L. Que Jr., B. G. Fox, K. Kauffmann and E. Münck, J. Am. Chem. Soc., 1995, 117, 2778; (b) Y. Zang, J. Kim, Y. Dong, E. C. Wilkinson, E. H. Appelman and L. Que Jr., J. Am. Chem. Soc., 1997, 119, 4197; (c) C. Kim, K. Chen, J. Kim and L. Que Jr., J. Am. Chem. Soc., 1997, 119, 5964; (d) K. Chen and L. Que Jr., J. Am. Chem. Soc., 2001, 123, 6327; (e) K. Chen, M. Costas, J. Kim, A. Tipton and L. Que Jr., J. Am. Chem. Soc., 2002, 124, 3026; (f) J. Y. Ryu, J. Kim, M. Costas, K. Chen, W. Nam and L. Que Jr., Chem. Commun., 2003, 1288.

9 M. Costas, A. K. Tipon, K. Chen, D.-W. Jo and L. Que Jr., J. Am. Chem. Soc., 2001, 123, 6722.
10 (a) K. Wieghardt, K. Pohl and W. Gebert, Angew. Chem., Int. Ed. Engl., 1983, 22, 727; (b) G. B. Shul'pin, G. V. Nizova, Y. N. Kozlov, L. Gonzales Cuervo and G. Süss-Fink, Adv. Synth. Catal., 2004, 346, 317.

11 A. Beck, B. Weibert and N. Burzlaff, Eur. J. Inorg. Chem., 2001, 521.

12 A. Beck, A. Barth, E. Hübner and N. Burzlaff, Inorg. Chem., 2003, 42, 7182.

13 P. D. Oldenburg, A. A. Shteinman and L. Que Jr., J. Am. Chem. Soc., 2005, 127, 15672.

14 S. J. Friesse, B. E. Kucera, L. Que Jr. and W. B. Tolman, Inorg. Chem., 2006, 45, 8003.

15 (a) P. C. A. Bruijnincx, M. Lutz, A. L. Spek, E. E. van Faassen, B. M. Weckhuysen, G. van Koten and R. J. M. Klein Gebbink, Eur. J. Inorg. Chem., 2005, 779; (b) P. C. A. Bruijnincx, M. Lutz, J. P. den Breejen, A. L. Spek, G. van koten and R. J. M. Klein Gebbink, J. Biol. Inorg. Chem., 2007, 12, 1181; (c) P. C. A. Bruijnincx, I. L. C. Buurmans, S. Gosiewska, M. A. H. Moelands, M. Lutz, A. L. Spek, G. van Koten and R. J. M. Klein Gebbink, Chem.-Eur. J., 2008, 14, 1228; (d) M. A. H. Moelands, S. Nijsse, E. Folkertsma, B. de Bruin, M. Lutz, A. L. Spek and R. J. M. Klein Gebbink, Inorg. Chem., 2013, 52, 7394-7410.

16 P. C. A. Bruijnincx, M. Lutz, A. L. Spek, W. R. Hagen, B. M. Weckhuysen, G. van Koten and R. J. M. Klein Gebbink, J. Am. Chem. Soc., 2007, 129, 2275.

17 L. Peters, E. Hubner and N. Burzlaff, J. Organomet. Chem., 2005, 690, 2009.

18 N. Burzlaff, Angew. Chem., Int. Ed., 2009, 48, 5580.

19 S. S. Rocks, W. W. Brennessel, T. E. Machonkin and P. L. Holland, Inorg. Chim. Acta, 2009, 362, 1387.

20 S. Paria, P. Halder and T. K. Paine, Inorg. Chem., 2010, 49, 4518.

21 (a) V. J. Dungan, B. M.-L. Poon, E. S. Barrett and P. J. Rutledge, Tetrahedron Lett., 2013, 54, 1236; (b) V. J. Dungan, S. M. Wong, S. M. Barry and P. J. Rutledge, Tetrahedron, 2012, 68, 3231. No structural data are presented in these studies.

22 (a) S. Gosiewska, J. L. M. Cornelissen, M. Lutz, A. L. Spek, G. van Koten and R. J. M. Klein Gebbink, Inorg. Chem., 2006, 45, 4214; (b) S. Gosiewska, M. Lutz, A. L. Spek and R. J. M. Klein Gebbink, Inorg. Chim. Acta, 2007, 360, 405.

23 G. Chelucci, M. Falorni and G. Giacomelli, Tetrahedron: Asymmetry, 1990, 1, 843.

24 P. Å. Bergström and R. French, J. Phys. Chem., 1995, 99, 12603.

25 G. J. P. Britovsek, V. C. Gibson, S. K. Spitzmesser, K. P. Tellmann, A. J. P. White and D. J. Williams, J. Chem. Soc., Dalton Trans., 2002, 1159.

26 D. F. Evans, J. Chem. Soc., 1959, 2003.

27 A. W. Addison, T. N. Rao, J. Reedijk, J. van Rijn and G. C. Verschoor, J. Chem. Soc., Dalton Trans., 1984, 1349.

28 G. G. Evans and J. A. Boeyens, Acta Crystallogr., Sect. B: Struct. Sci., 1989, 45, 581. 
29 M. A. H. Moelands, S. Nijsse, E. Folkertsma, B. de Bruin, M. Lutz, A. L. Spek and R. J. M. Klein Gebbink, Inorg. Chem., 2013, 52, 7394.

30 B. L. Small and M. Brookhart, Macromolecules, 1999, 32, 2120.

31 F. Pelascini, M. Wesolek, F. Peruch and P. J. Lutz, Eur. J. Inorg. Chem., 2006, 21, 4309.

32 C. Dowling, V. J. Murphy and G. Parkin, Inorg. Chem., 1996, 35, 2415.

33 M. Biswas, G. Pilet, M. S. El Fallah, J. Ribas and S. Mitra, Inorg. Chim. Acta, 2008, 361, 387.

34 A. J. Amoroso, M. W. Burrows, S. J. Coles, R. Haigh, R. D. Farley, M. B. Hursthouse, M. Jones, K. M. A. Malik and D. M. Murphy, Dalton Trans., 2008, 506.

35 F. H. Allen, Acta Crystallogr., Sect. B: Struct. Sci., 2002, 58, 380-388.

36 (a) G. Argay, A. Kalman and V. M. Leovac, Acta Crystallogr., Sect. C: Cryst. Struct. Commun., 1999, 55, 1440; (b) M. A. Yampol'skaya, S. G. Shova, Yu. A. Simonov, N. V. Gerbeleu, K. I. Turte and V. E. Zavodnik, Russ. J. Inorg. Chem., 1985, 30, 1221; (c) P. V. Bernhardt, P. Chin, P. C. Sharpe, J.-Y. C. Wang and D. R. Richardson, J. Biol. Inorg. Chem., 2005, 10, 761; (d) D. Urakami, K. Inoue and S. Hayami, Acta Crystallogr., Sect. E: Struct. Rep. Online, 2009, 65, m800; (e) H. Liu, Y. Kou, L. Feng, D. Li, C.-Y. Gao, J. Tian, J. Zhang and S. Yan, Appl. Organomet. Chem., 2010, 24, 636; $(f)$ Z. D. Tomic, V. M. Leovac, Z. K. Jacimovic, G. Giester and S. D. Zaric, Inorg. Chem. Commun., 2006, 9, 833; $(g)$ N. Kleigrewe, W. Steffen, T. Blomker, G. Kehr, R. Frohlich, B. Wibbeling, G. Erker, J.-C. Wasilke, G. Wu and G. C. Bazan, J. Am. Chem. Soc., 2005, 127, 13955; (h) V. C. Gibson, C. Redshaw, G. A. Solan, A. J. P. White and D. J. Williams, Organometallics, 2007, 26, 5119; (i) R. K. O'Reilly, V. C. Gibson, A. J. P. White and
D. J. Williams, J. Am. Chem. Soc., 2003, 125, 8450; (j) F. A. R. Kaul, G. T. Puchta, G. D. Frey, E. Herdtweck and W. A. Herrmann, Organometallics, 2007, 26, 988; (k) N. J. Hardman, X. Fang, B. L. Scott, R. J. Wright, R. L. Martin and G. J. Kubas, Inorg. Chem., 2005, 44, 8306; (l) W.-S. Wu and S.-X. Liu, Chem. J. Chin. Univ., 2003, 24, 2137; (m) Y. Yamaguchi, H. Ando, M. Nagaya, H. Hinago, T. Ito and M. Asami, Chem. Lett., 2011, 40, 983.

37 H. Vahrenkamp, Acc. Chem. Res., 1999, 32, 589.

38 A. Company, L. Gómez, X. Fontrodona, X. Ribas and M. Costas, Chem.-Eur. J., 2008, 14, 5727.

39 F. G. Gelalcha, B. Bitterlich, G. Anilkumar, M. K. Tse and M. Beller, Angew. Chem., Int. Ed., 2007, 46, 7293.

40 K. S. Hagen, Inorg. Chem., 2000, 39, 5867.

41 G. Suster, S. A. Stoykova, A. Linden and H. Heimgartner, Helv. Chim. Acta, 2000, 83, 2961.

42 A. J. M. Duisenberg, L. M. J. Kroon-Batenburg and A. M. M. Schreurs, J. Appl. Crystallogr., 2003, 36, 220.

43 A. M. M. Schreurs, X. Xian and L. M. J. Kroon-Batenburg, J. Appl. Crystallogr., 2010, 43, 70.

44 Z. Otwinowski and W. Minor, Methods in Enzymology, Volume 276, ed. C. W. Carter Jr. and R. M. Sweet, Academic Press, 1997, pp. 307-326.

45 G. M. Sheldrick, SADABS: Area-Detector Absorption Correction, v2.10, Universität Göttingen, Germany, 1999.

46 R. H. Blessing, Acta Crystallogr., Sect. A: Fundam. Crystallogr., 1995, 51, 33.

47 G. M. Sheldrick, Acta Crystallogr., Sect. A: Fundam. Crystallogr., 2008, 64, 112.

48 A. Altomare, M. C. Burla, M. Camalli, G. L. Cascarano, C. Giacovazzo, A. Guagliardi, A. G. G. Moliterni, G. Polidori and R. Spagna, J. Appl. Crystallogr., 1999, 32, 115.

49 A. L. Spek, Acta Crystallogr., Sect. D: Biol. Crystallogr., 2009, 65, 148. 